\title{
SERIES
}

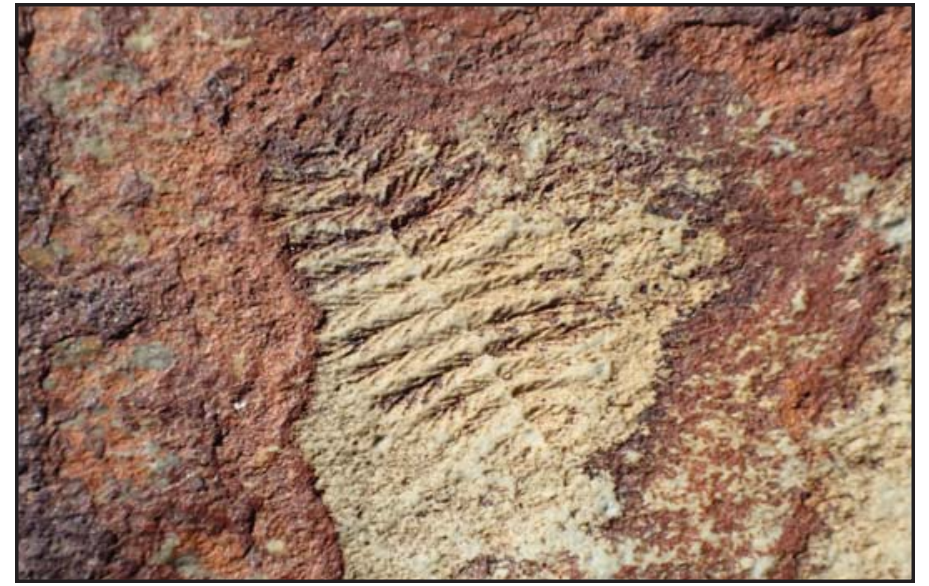

\section{Great Canadian Lagerstätten 6. Mistaken Point Ecological Reserve, Southeast Newfoundland}

\author{
Alexander G. Liu ${ }^{1}$ and Jack J. Matthews ${ }^{2,3}$ \\ ${ }^{1}$ Department of Earth Sciences \\ University of Cambridge \\ Downing Street, Cambridge, CB2 3EQ, United Kingdom \\ E-mail:agscl2@cam.ac.uk. \\ ${ }^{2}$ Department of Earth Sciences \\ Memorial University of Newfoundland \\ Alexander Murray Building, 300 Prince Philip Drive \\ St. John's, Nenfoundland and Labrador, A1B 3X5, Canada \\ ${ }^{3}$ Oxford University Museum of Natural History \\ Parks Road, Oxford, OX1 3PW, United Kingdom
}

\section{SUMMARY}

Mistaken Point Ecological Reserve (MPER) World Heritage Site, on the southeastern coast of Newfoundland, Canada, is one of the foremost global Ediacaran fossil localities. MPER contains some of the oldest known assemblages of the softbodied Ediacaran macrobiota, and its fossils have contributed significantly to Ediacaran paleobiological research since their initial discovery in 1967. Preservation of multiple in situ benthic paleocommunities, some comprising thousands of specimens, has enabled research into Ediacaran paleoecology, ontogeny, taphonomy, taxonomy and morphology, offering insights into the possible phylogenetic positions of Ediacaran taxa within the tree of life. Meanwhile, a thick and continuous geological record enables the fossils to be placed within a wellresolved temporal and paleoenvironmental context spanning an interval of at least 10 million years. This article reviews the history of paleontological research at MPER, and highlights key discoveries that have shaped global thinking on the Ediacaran macrobiota.

\section{RÉSUMÉ}

Le site du Patrimoine mondial de la Réserve écologique de Mistaken Point (MPER), sur la côte sud-est de Terre-Neuve, au Canada, est l'une des principales localités fossilifères édiacariennes de la planète. Le MPER renferme quelques-uns des plus anciens assemblages connus de macrobiote édicarien à parties molles, et ses fossiles ont contribué de manière significative à la recherche paléobiologique édiacarienne depuis leur découverte en 1967. La préservation de multiples paléocommunautés benthiques in situ, dont certaines comptant des milliers de spécimens, a permis de faire des recherches en paléoécologie, ontogenèse, taphonomie, taxonomie et morphologie de biotes édiacariens, ce qui a permis d'avoir un aperçu de différentes positions phylogénétiques possibles des taxons édiacariens dans l'arborescence biologique. Aussi, grâce à une colonne géologique épaisse et continue, on a pu placer ces fossiles dans un contexte temporel et paléoenvironnemental bien circonscrit qui s'étend sur un intervalle d'au moins 10 millions d'années. Cet article passe en revue l'histoire de la recherche paléontologique au MPER et souligne les découvertes majeures qui ont façonné la réflexion sur le macrobiote édiacarien.

Traduit par le Traducteur

\section{INTRODUCTION}

The barren southeastern coastline of Newfoundland, Canada, can be a wild and mysterious place. Intense post-tropical cyclones in the fall, and ferocious Atlantic winter storms that bring snow, ice, and howling gales, combine with destructive effect to shape the rugged cliffs. During the summer, the coastline is at times barely visible beneath a dense veil of fog and mist that sits atop the landscape for weeks on end. It is only in the late summer months when the fog lifts that the area's natural riches can be truly appreciated. A unique ecological biome (the Eastern Hyper-oceanic Barrens; Damman 1983; Meades 1990), coupled with spectacular rocky scenery 

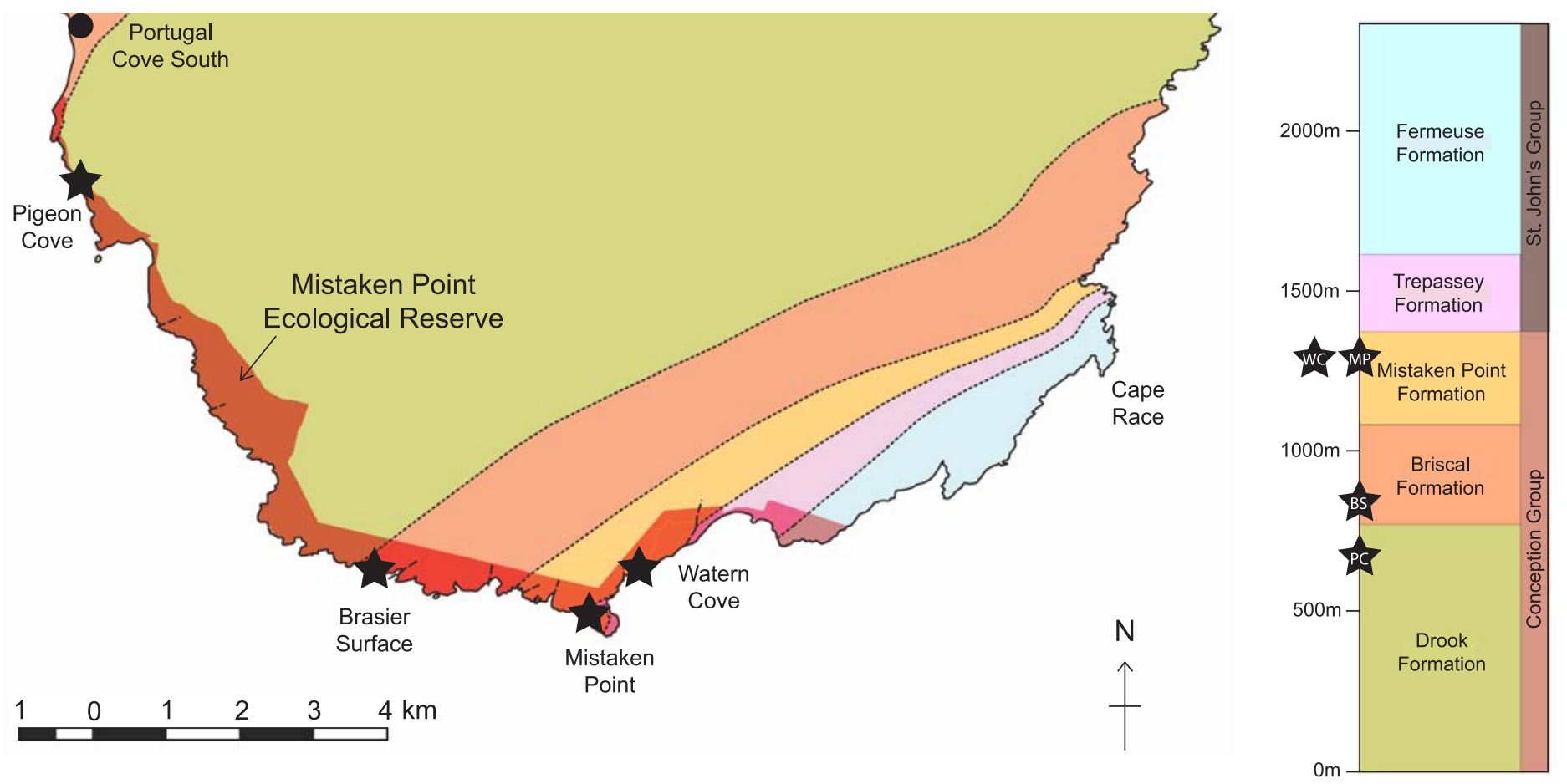

Figure 1. Geological map and stratigraphy of Mistaken Point Ecological Reserve (MPER), showing key fossil localities and their relative stratigraphic positions (black stars). Red shading indicates the areal extent of MPER.

and diverse bird and marine life, would be sufficient cause for the designation of this coastline as a provincial Ecological Reserve. However, even more remarkable, but less easy to see on the weather-worn rock surfaces, are countless impressions of soft-bodied organisms that inhabited the seafloor $\sim 565$ million years ago. These fossils, dating from the middle-late Ediacaran period, have proven amongst the most difficult to decipher in the entire geological record, but they are crucial to shaping our understanding of the early evolution of large, morphologically complex organisms (Narbonne 2005; Fedonkin et al. 2007; Attenborough 2010).

Ediacaran fossils were first discovered at the prominent headland called Mistaken Point in the summer of 1967. Shiva Balak Misra, a geology M.Sc. student at Memorial University of Newfoundland, was undertaking a mapping project (Misra 1969a) when he and his field assistant, Paul Thompson, recognized unusual and diverse impressions preserved on the bedding surfaces. Amongst the discoveries were spindle-shaped, leaf-shaped, lobate and radiating forms, which were recognized to comprise a new Canadian biota that was demonstrably Precambrian in age. Misra reported the discovery in Nature with Michael Anderson of Memorial University (Anderson and Misra 1968), and then documented the fossils in more detail the following year (Misra 1969b). Correspondence with Professor Martin Glaessner in Adelaide confirmed to Misra that the Mistaken Point specimens were similar to those being found in the Ediacara Hills of Australia (Glaessner and Wade 1966), and in Charnwood Forest of the UK (Ford 1958). Together with specimens from Russia and Namibia, these assemblages gave rise to the concept of a globally distributed "Ediacara biota:" an eclectic assortment of largely soft-bodied organisms that inhabited the ocean floor in the $\sim 30$ million years immediately preceding the Cambrian period.

The Mistaken Point fossils represent some of the most spectacular occurrences of soft-bodied macro-organisms in the geological record. Thousands of specimens are found on numerous natural exposures of laterally continuous bedding planes through the siliciclastic sedimentary successions of the Conception and St. John's groups (Fig. 1). These fossils include some of the oldest known records of large and complex macrofossils, metazoan trace fossils, and complex macroscopic ecosystems (Liu and Brasier 2012; Thomas et al. 2015). Ediacaran assemblages from the White Sea in Russia (e.g. Zakrevskaya 2014), and the Flinders Ranges in Australia (Droser and Gehling 2015), can be better preserved and document a wider variety of organisms than those in Newfoundland. However, the Newfoundland assemblages are several million years older than these other sites, and reflect deeper marine depositional environments (Boag et al. 2016). The Mistaken Point Ecological Reserve (MPER) fossil-bearing bedding planes are also unusual in that they occur through a considerable thickness of sediment, documenting a deep marine but broadly shallowing upwards sedimentary environment (Wood et al. 2003). Fossils, preserved as epirelief impressions and ranging from a few millimetres to over one metre in dimension, can reach densities of over 100 individuals per square metre on some surfaces (Clapham et al. 2003). They are often difficult to see due to their low topographic relief, but under low-angle sunlight they provide an unprecedented paleontological spectacle (Fig. 2a).

The MPER succession has contributed to well over $100 \mathrm{sci}-$ entific publications to date, and has proven to be our most 

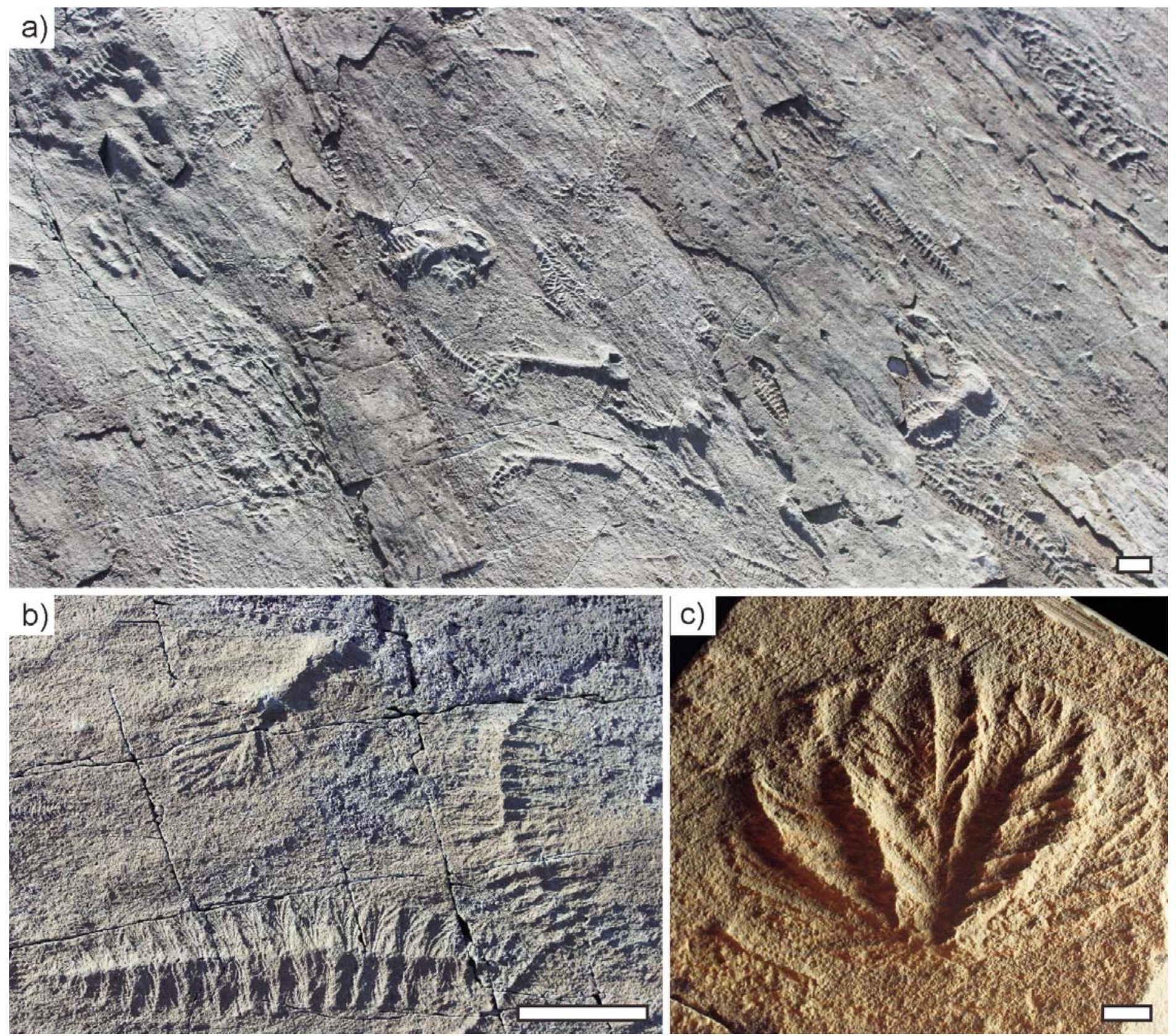

Figure 2. Fossils of the Mistaken Point 'D' and 'E' surfaces, Mistaken Point Formation. a) Dense assemblages of Ediacaran macrofossils, representing at least 8 different taxa in this image, on the 'E' Surface. b) The Ediacaran macrofossils Plumeropriscum (top centre) and Fractofusus misrai (bottom and right) on the 'E' Surface. c) Bradgatia from Watern Cove, clearly showing displayed 'self-similar' rangeomorph branches, ROM 36500 . Scale bars a-b) $=50 \mathrm{~mm}, \mathrm{c})=10 \mathrm{~mm}$.

informative record of deep marine Ediacaran macrofossil assemblages. The fossils are becoming increasingly appreciated outside of academia, and have featured in artwork, poetry, books, and television documentaries. The scientific importance of the fossils around Mistaken Point was recognized by the Government of Newfoundland and Labrador in 1987, with the establishment of the Mistaken Point Ecological Reserve to encompass an $8.5 \mathrm{~km}$ stretch of coastline spanning $5.7 \mathrm{~km}^{2}$. The Reserve was expanded to its current $17 \mathrm{~km}$ extent in 2003 to include a number of newly discovered fossil surfaces. Following almost a decade of preparation, MPER was added to the UNESCO World Heritage List on July $17^{\text {th }} 2016$, joining Miguasha National Park, Joggins Fossil Cliffs, Dinosaur Provincial Park, and the Canadian Rocky Mountains Park (home to the Burgess Shale) as one of Canada's five UNESCO World Heritage Sites inscribed at least in part on the basis of their paleontological attributes.

\section{The Ediacaran Enigma}

The Ediacaran macrobiota, 570-541 Ma, comprises the first diverse populations of large and complex organisms in the fossil record (Fedonkin et al. 2007). Determining what sort of organisms were present among the biota is important for understanding the causes and consequences of both the rise of 
macroscopic multicellularity, and potentially the origin and diversification of animals (Budd and Jensen 2017; Cunningham et al. 2017). Indeed, resolving the biological affinities of the biota and their relationship to extant eukaryotic groups such as animals and algae is a major outstanding goal in the field of paleobiology.

Considerable biotic diversity had already been achieved prior to the appearance of the Ediacaran macrobiota. Bacteria and acritarchs are abundant among Proterozoic microfossils (Vidal and Moczydlowska-Vidal 1997), while evidence for testate amoebae (Bosak et al. 2011a), ciliates (Bosak et al. 2011b), foraminifera (Bosak et al. 2012), and largely sub-centimetric algae (Butterfield 2009; Zhu et al. 2016), fungi (Butterfield 2005) and rare putative animals (Yin et al. 2015) all predates the Ediacaran period.

The precise temporal and spatial distribution of the Ediacaran macrobiota remains to be fully constrained, and is likely to have been influenced by paleogeography, facies variation, and incompleteness of the fossil record (Waggoner 2003; Grazhdankin 2004, 2014; Droser et al. 2006; Gehling and Droser 2013; Boag et al. 2016). The earliest known Ediacaran macroscopic fossils are probably the Lantian biota of China, which includes possible animals (Wan et al. 2016) alongside several macroscopic algal taxa (Yuan et al. 2011). These are followed by specimens from Newfoundland and the U.K., together referred to as the Avalon assemblage (Waggoner 2003), which were $\sim 570-560 \mathrm{Ma}$. More diverse assemblages from the White Sea coastline of Russia, and South Australia, follow at around $\sim 560 \mathrm{Ma}$ (summarized in Fedonkin et al. 2007; Dunn and Liu 2017). After reaching their zenith $\sim 555$ million years ago (Boag et al. 2016), the Ediacaran macroorganisms appear to diminish in diversity and number, with the depauperate Nama assemblage of Namibia (Darroch et al. 2015), barring a few rare potential Cambrian survivors (e.g. Conway Morris 1993; Jensen et al. 1998), long thought to represent the last of the soft-bodied Ediacaran macrobiota. Recent research suggests that a globally abundant latest Ediacaran assemblage of fossils with tubular morphologies, some of which were capable of organic or calcium carbonate biomineralization, span the latest Ediacaran-Cambrian transition (e.g. Warren et al. 2012; Smith et al. 2016). The relationships between late Ediacaran organisms and those of the Phanerozoic remain unclear, although there is a growing belief that the Ediacaran macrobiota reflects a diverse, polyphyletic assemblage of organisms allied to a variety of eukaryotic clades (Xiao and Laflamme 2009; Laflamme et al. 2013; Liu et al. 2015).

From a geological perspective, the initial appearance and subsequent apparent decline of the Ediacaran macrobiota and associated organisms raise questions about the interplay between life and the biosphere. A variety of major geological and environmental events are documented during the late Neoproterozoic, including at least two geographically widespread and long-lived glacials (the Sturtian, 717-660 Ma, and the Marinoan, ending $\sim 635 \mathrm{Ma}$; Rooney et al. 2015); the breakup of the supercontinents of Rodinia and Pannotia from $\sim 700$ Ma (Li et al. 2008; Scotese 2009); significant global perturba- tions in carbon, sulphur and oxygen stable isotope records (Halverson et al. 2005; Bristow and Kennedy 2008; Le Guerroué 2010); a rise in atmospheric and deep marine oxygen concentrations (Fike et al. 2006; Shields-Zhou and Och 2011; Lyons et al. 2014); and increasing stability in oxic conditions from latest Ediacaran into earliest Cambrian shelf settings (Johnston et al. 2012). Each of these changes has been postulated to have potential links to the evolution of the Ediacaran macrobiota (e.g. Cloud Jr. 1968; Dalziel 1997; Narbonne and Gehling 2003; Catling et al. 2005; Canfield et al. 2007). Further questions include why the soft-bodied Ediacaran macrobiota appeared $\sim 570$ million years ago, and essentially disappear from the record at the basal Cambrian boundary? How did the inception of metazoan burrowing and biomineralization in the latest Ediacaran period (Buatois and Mángano 2011; Wood 2011), or the demise of benthic microbial communities (Seilacher and Pfluger 1994; Bottjer et al. 2000), influence global nutrient cycling (Boyle et al. 2014), or affect the preservation potential of soft tissues (Callow and Brasier 2009)? Efforts are ongoing to refine age models in order to correlate cause and effect more precisely across this interval (e.g. Pu et al. 2016).

\section{History of Research into the Ediacaran Fossils of Newfoundland}

The type sections that document the very end of the Ediacaran System, namely the Global Stratotype Section and Point for the Ediacaran-Cambrian boundary (Brasier et al. 1994), are located on the Burin Peninsula of Newfoundland. Those sections contain a small number of latest Ediacaran body fossils (e.g. Palaeopascichnus and vendotaenids) and trace fossils, but the majority of Newfoundland's Ediacaran macrofossils are around 20-30 million years older, and are found on the Avalon and Bonavista peninsulas.

Research into the Ediacaran fossils of Newfoundland began in 1872 with the description of the discoidal fossil Aspidella terranovica from Precambrian rocks in downtown St. John's (Billings 1872). The biological nature of that material was questioned for many years (summarized in Boyce and Reynolds 2008), but has been confirmed by Gehling et al. (2000), who interpreted the impressions as probable holdfasts of frondose taxa. Interestingly, it is almost certain that such discoidal fossils were observed, even if their biological interest was not recognized, by some of the first European settlers in Newfoundland, since Aspidella fossils can be found in the flagstones of house foundations dating to the 1600s in the town of Ferryland on the east coast of the island.

Misra's discoveries at Mistaken Point in the late 1960s precipitated considerable exploration of the region, aided in part by the mapping exploits of Williams and King (1979). Much of this exploration was led by Michael Anderson of Memorial University, who reviewed the different fossils in the region, and largely concluded that they were either of uncertain biological origin, or colonial cnidarians (Anderson 1978; Anderson and Conway Morris 1982). Meanwhile, sedimentological and stratigraphic studies (Williams and King 1979; Gardiner and Hiscott 1988; Landing et al. 1988) developed a geological and paleo- 
geographical framework within which to interpret the fossil assemblages (summarized by Conway Morris 1989).

Throughout the 1980s and 1990s, the Newfoundland fossils were often marshalled as evidence in discussions regarding the phylogenetic position of the Ediacaran macrobiota (Conway Morris 1985). Dolf Seilacher, in particular, worked on several of the fossil assemblages at MPER, and the Vendozoa and Vendobionta concepts he and his colleagues developed drew heavily on his examination of those specimens (Seilacher 1989, 1992; Buss and Seilacher 1994). Seilacher's research has also proven highly influential in shaping how study of not only the Newfoundland taxa, but the Ediacaran macrobiota as a whole, has been approached by future generations of researchers.

Research efforts in Newfoundland increased from the late 1990s onwards, as Guy Narbonne and his group from Queen's University, Ontario, investigated the sites around Mistaken Point (Thomas et al. 2015). They discovered a host of new fossil-bearing surfaces, and set about completing formal taxonomic descriptions of the fossils (e.g. Clapham et al. 2004; Laflamme et al. 2004; Gehling and Narbonne 2007; Laflamme et al. 2007; Bamforth and Narbonne 2009; Mason and Narbonne 2016), assessing aspects of their paleoecology (Clapham and Narbonne 2002; Clapham et al. 2003; Laflamme et al. 2012b), and interpreting the paleoenvironments represented within the stratigraphic succession (Wood et al. 2003). Members of that group continue to explore paleoecological questions relating to the fossil assemblages in Newfoundland, increasingly utilizing quantitative statistical and computational techniques to assess data collected from the MPER bedding planes (Clapham 2011; Darroch et al. 2013; Ghisalberti et al. 2014).

In 2002, Martin Brasier of the University of Oxford, in collaboration with former student Duncan Mcllroy at Memorial University of Newfoundland, began to study the Newfoundland Ediacaran sites in order to compare the specimens to similar fossils in the U.K. (Antcliffe and Brasier 2007). The work of Brasier and his colleagues initially focused on determining evolutionary relationships (Brasier and Antcliffe 2009) and taphonomic processes (e.g. Callow and Brasier 2009), and constraining the influence of time-averaging on fossil assemblage composition (Liu et al. 2011). It later expanded to incorporate taxonomy (Brasier et al. 2012), ichnology (Liu et al. 2010), paleoecology (Liu et al. 2012), and most recently geochronology, stratigraphy, and sedimentology.

The past decade has witnessed a period of unparalleled growth in research into the Ediacaran biota, both globally and within Newfoundland, as the enigmatic nature of the organisms has attracted public attention. Additional major Ediacaran fossil localities have been described from the Catalina Dome of the Bonavista Peninsula (O'Brien and King 2004; Hofmann et al. 2008), and Spaniard's Bay (Narbonne 2004; Narbonne et al. 2009), significantly embellishing Newfoundland's Ediacaran paleobiological riches. These new sites have revealed several additional taxa (Hofmann et al. 2008; Narbonne et al. 2009), and include probable identifiable metazoan body fossils (Liu et al. 2014a). However, the majority of studies into Ediacaran paleocommunities have continued to focus on material from
Mistaken Point Ecological Reserve. These include statistical studies into reproduction and paleoecology (Mitchell et al. 2015); study of lateral heterogeneity within paleocommunities on individual bedding planes (Matthews et al. 2017); study of growth within rangeomorph taxa (e.g. Hoyal Cuthill and Conway Morris 2014); discussion of sedimentary environments (Retallack 2013) and taphonomy (Liu 2016); and preliminary attempts to resolve the phylogenetic relationships between frondose taxa (Dececchi et al. 2017).

\section{MISTAKEN POINT ECOLOGICAL RESERVE}

The following sections review some of the major contributions that MPER has made to scientific understanding of the late Ediacaran interval.

\section{Paleobiology}

Fossils are known from over 80 bedding planes within the Mistaken Point Ecological Reserve, but the vast majority of studies have focused on just a handful of bedding surfaces. Principal among these are the Pigeon Cove surfaces in the Drook Formation (Fig. 3b-e), and the ' $\mathrm{D}$ ' and ' $\mathrm{E}$ ' surfaces at Mistaken Point itself (Landing et al. 1988; Figs. 2, 4a). The 'D' and 'E' surfaces were the first fossil-bearing horizons to be discovered by Misra, and each possesses over 1000 individual specimens (Clapham et al. 2003). The daunting task of taxonomic description of the various taxa has largely been completed by the Queen's University group. This work has identified forms described from other global sites amongst the Mistaken Point assemblages (e.g. Charnia, Charniodiscus and Bradgatia; Laflamme et al. 2004, 2007; Flude and Narbonne 2008), but has also introduced several new taxa (e.g. Thectardis Clapham et al. 2004; Fractofusus Gehling and Narbonne 2007; Pectinifrons Bamforth et al. 2008; Trepassia Narbonne et al. 2009; Hapsidophyllas and Frondophyllas Bamforth and Narbonne 2009; Culmofrons Laflamme et al. 2012b; Plumeropriscum and Broccoliforma Mason and Narbonne 2016), many of which appear to be endemic to Newfoundland. Supplemented by forms documented by other researchers (e.g. Primocandelabrum Hofmann et al. 2008; Beothukis Brasier and Antcliffe 2009; Vinlandia Brasier et al. 2012), the vast majority of macrofossils found within MPER have now been formally described.

The biological affinities of the Mistaken Point macrofossils have, as with the wider Ediacaran soft-bodied macrobiota, been much debated. Most early work on the Mistaken Point organisms considered them to belong to cnidarian clades (e.g. Misra 1969b; Anderson 1978; Anderson and Conway Morris 1982), while similar forms elsewhere in the Avalon region were considered as possible algae (Ford 1958). The subsequent suggestion that the Ediacaran macrobiota may form a discrete clade belonging to an entirely extinct kingdom or phylum, the 'Vendobionta' (Seilacher 1989, 1992, 1999, 2007), provoked consideration of a host of metazoan and non-metazoan biological affinities for members of the Mistaken Point assemblages (summarized in Narbonne 2005). Current thinking supports the view that the biota likely includes members of several diverse phyla and kingdoms, and the biology of each taxon should be assessed on a case-by-case basis (Xiao and 


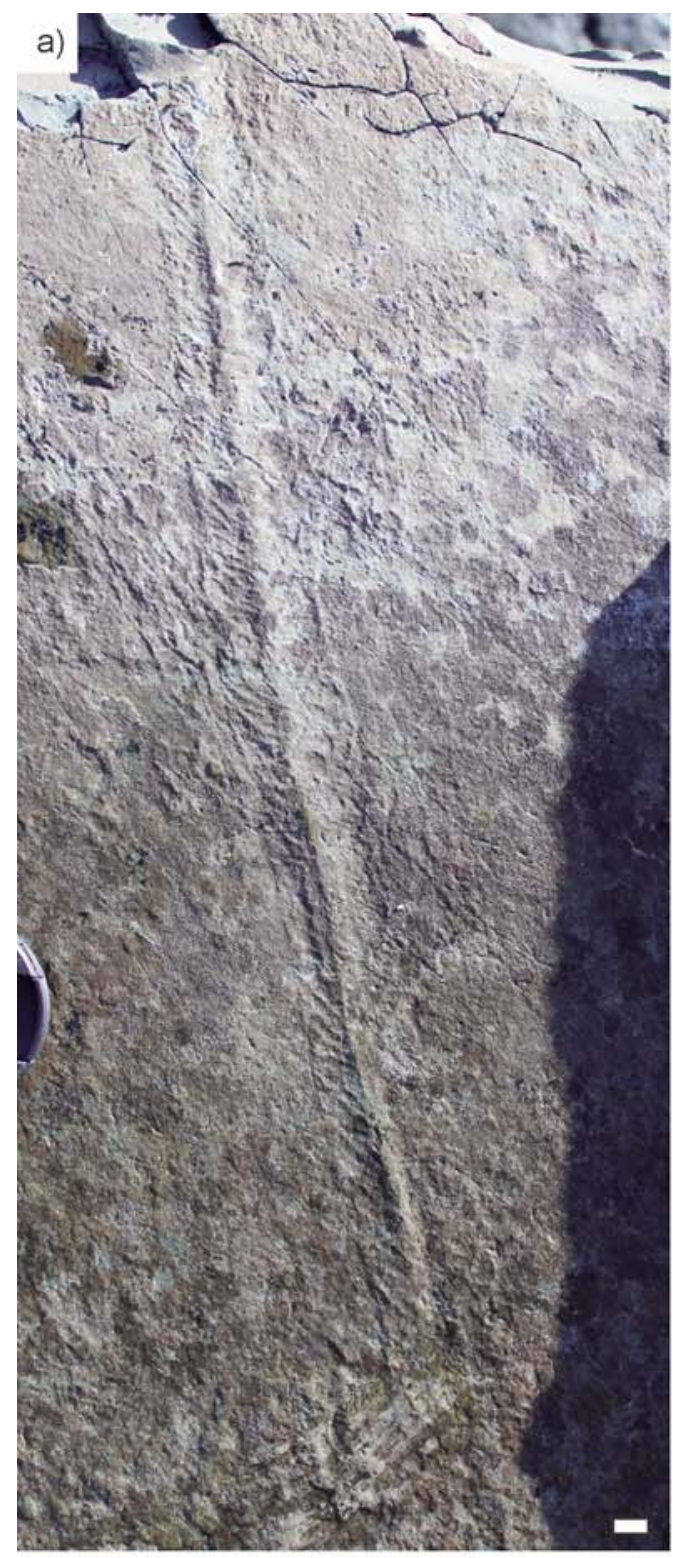

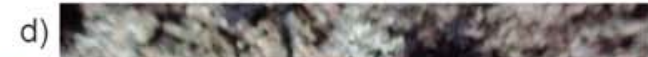

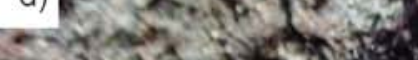

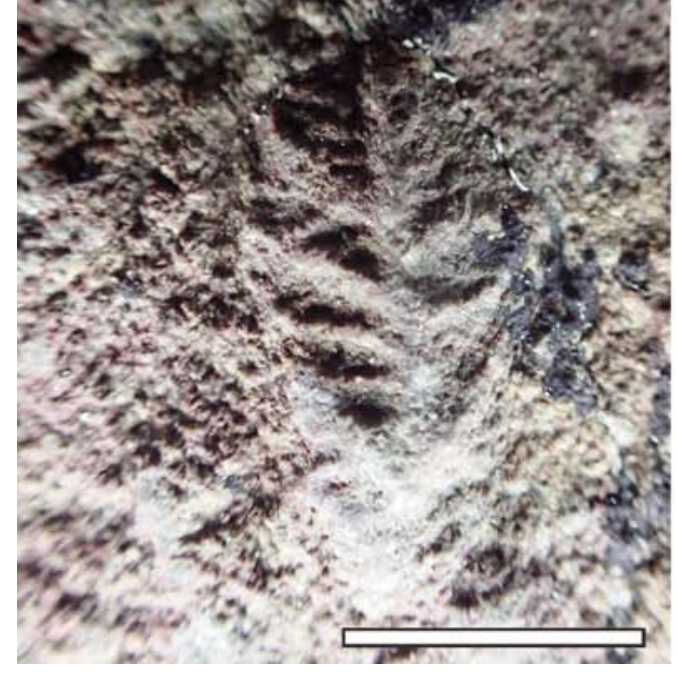

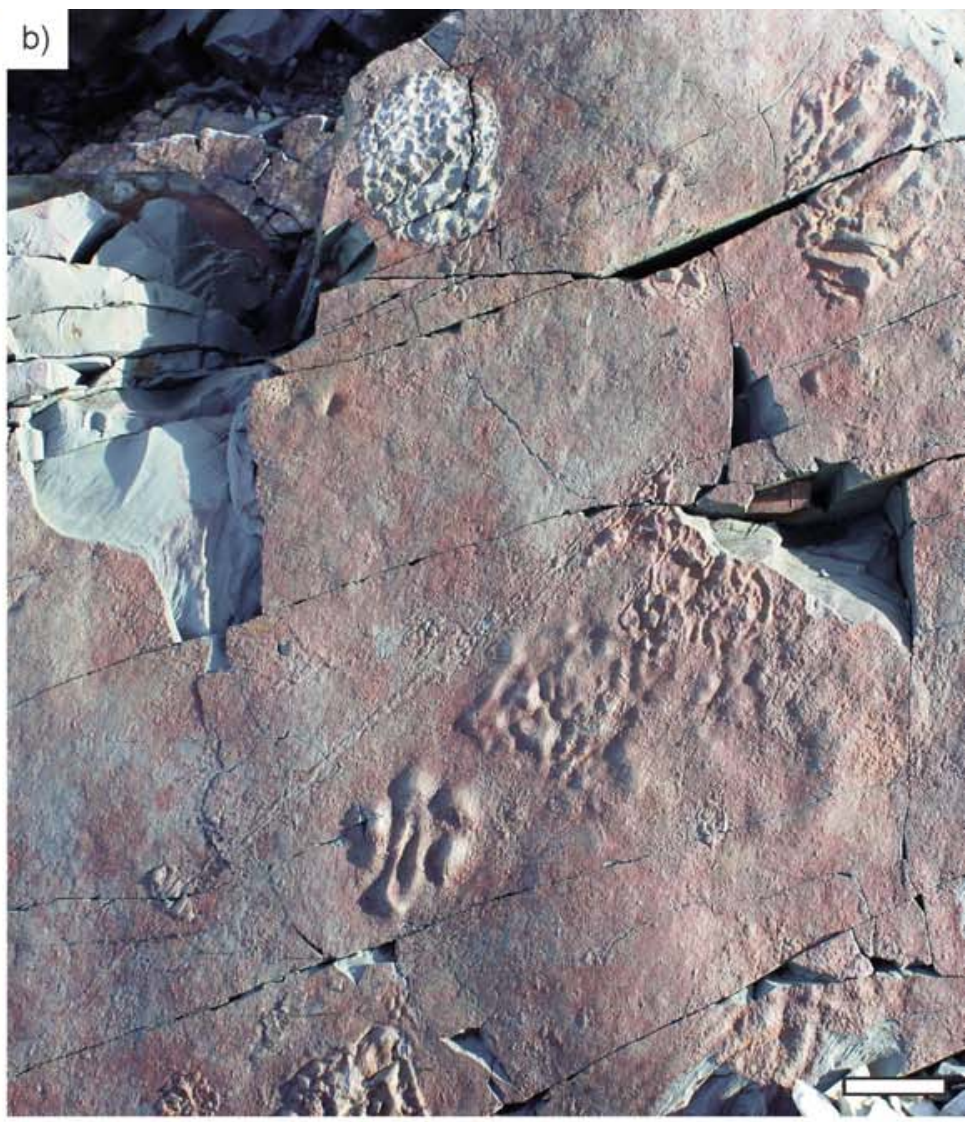
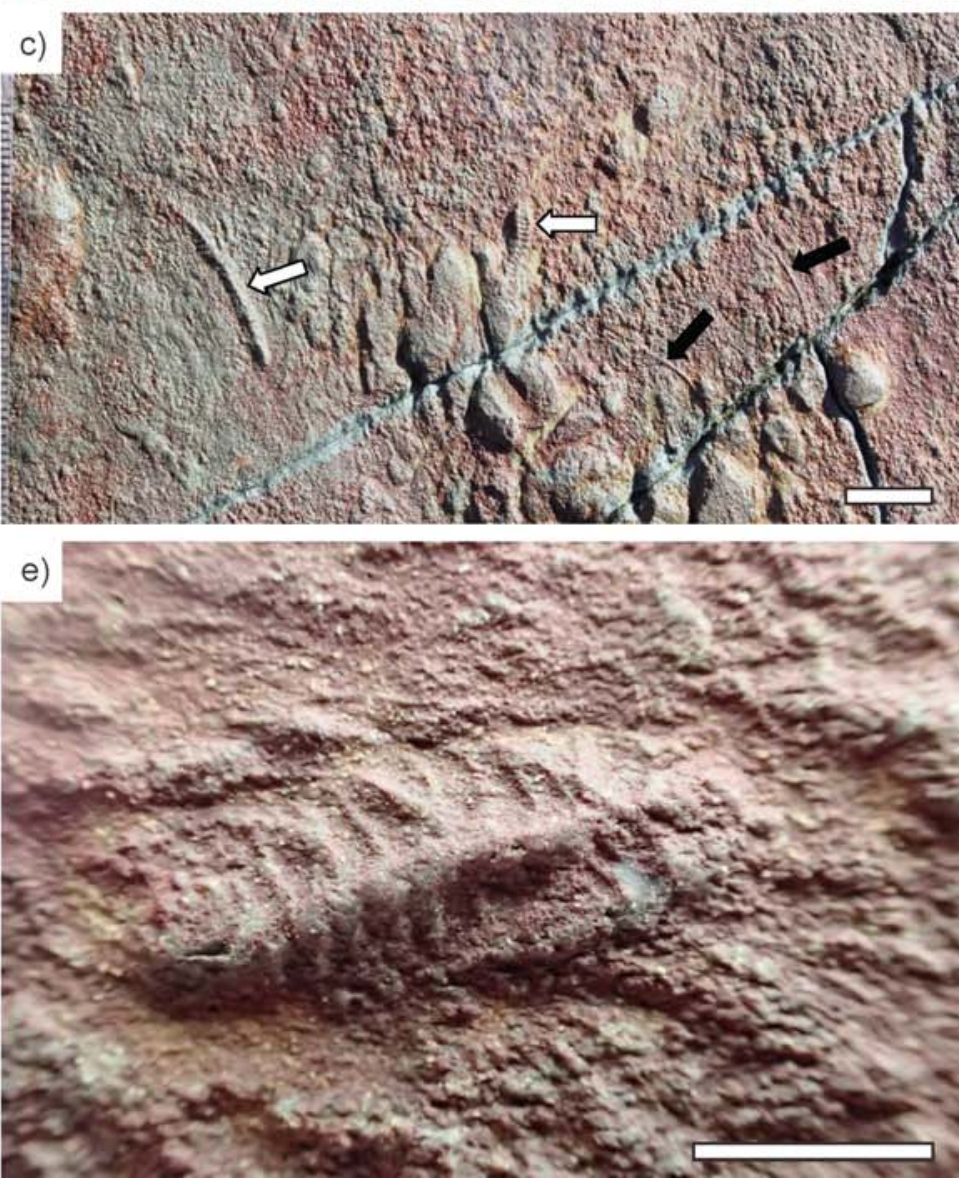

Figure 3. Notable fossils from the Drook Formation of the Mistaken Point Ecological Reserve. a) The rangeomorph Trepassia wardae from the Drook Formation, one of the oldest macrofossil taxa observed in the
region. b) Ivesheadiomorph fossils in the Drook Formation at Pigeon Cove. c) Small fronds (white arrows) and filamentous impressions (black arrows) on the Pigeon Cove surface. d-e) Small (rangeomorph?) fronds at Pigeon Cove. Scale bars = $10 \mathrm{~mm}$, except de) $=5 \mathrm{~mm}$. 
a)

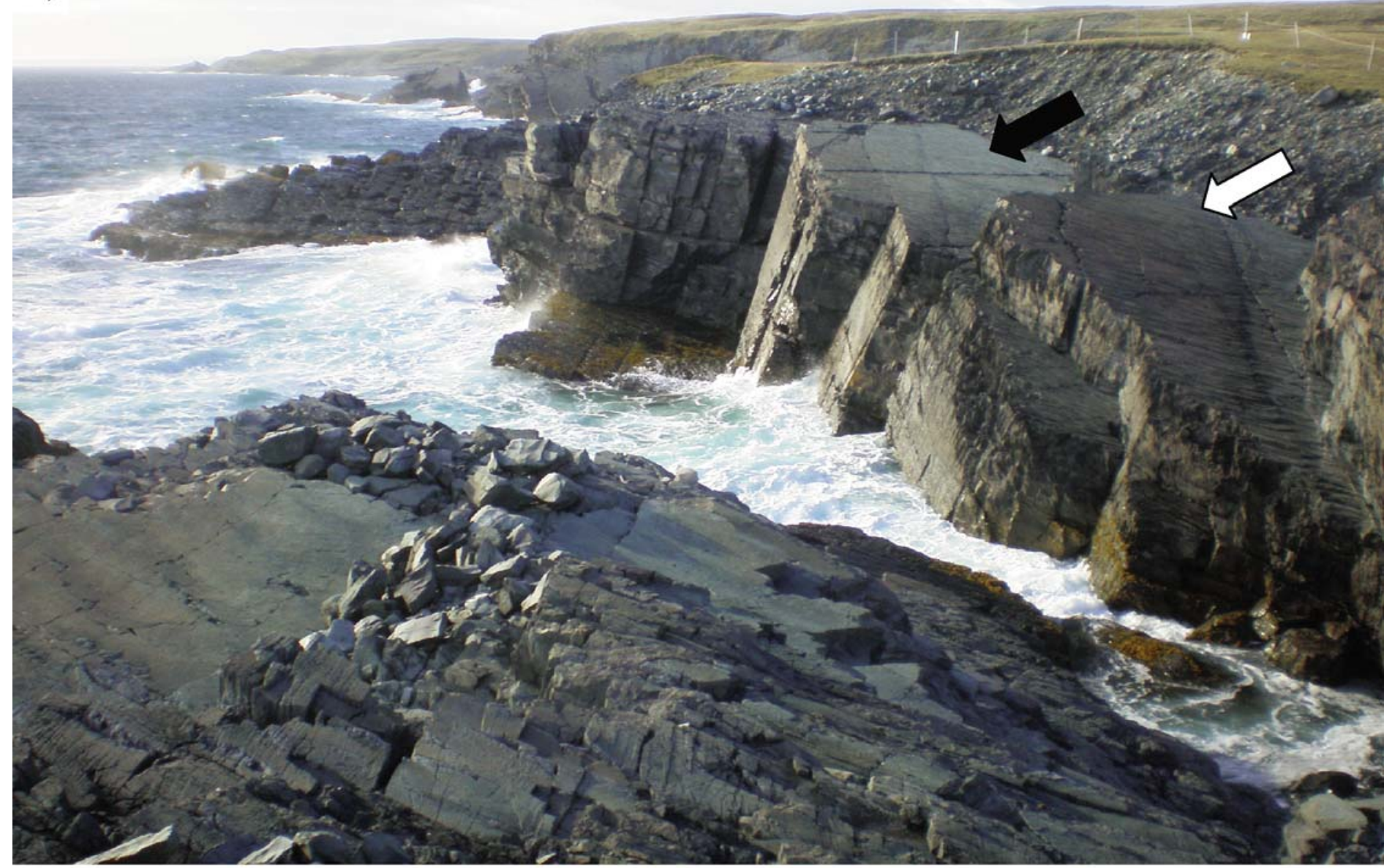

b)
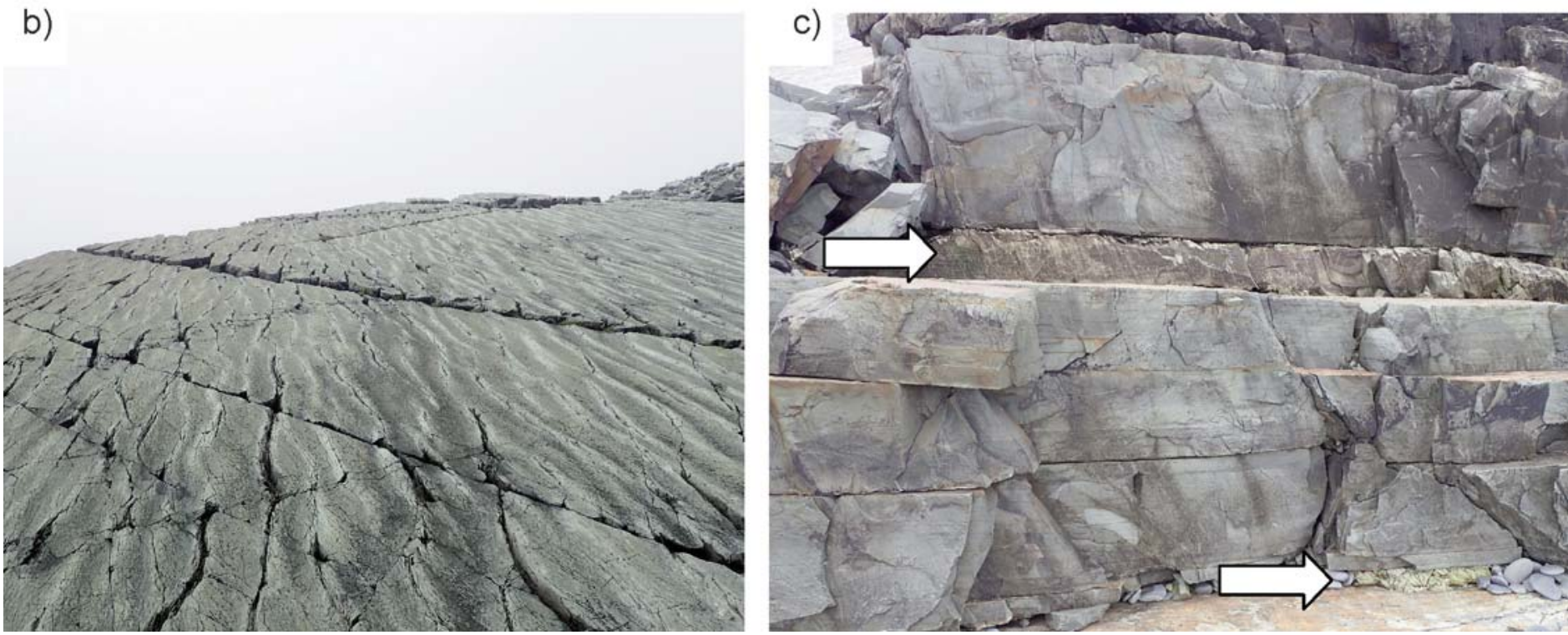

Figure 4. Geology of Mistaken Point Ecological Reserve. a) View of the 'D' (black arrow) and 'E' (white arrow) surfaces at Mistaken Point, and additional Ediacaran bedding planes that extend along the coast. b) Tectonic ripples and fractures on the 'D' Surface. c) Prominent tuff bands (arrowed) on fossil-bearing surfaces in the Drook Formation at Pigeon Cove. Zircon crystals from such tuff layers can be used for U-Pb ID-TIMS geochronology, enabling precise dating of the associated fossil-bearing surfaces. 

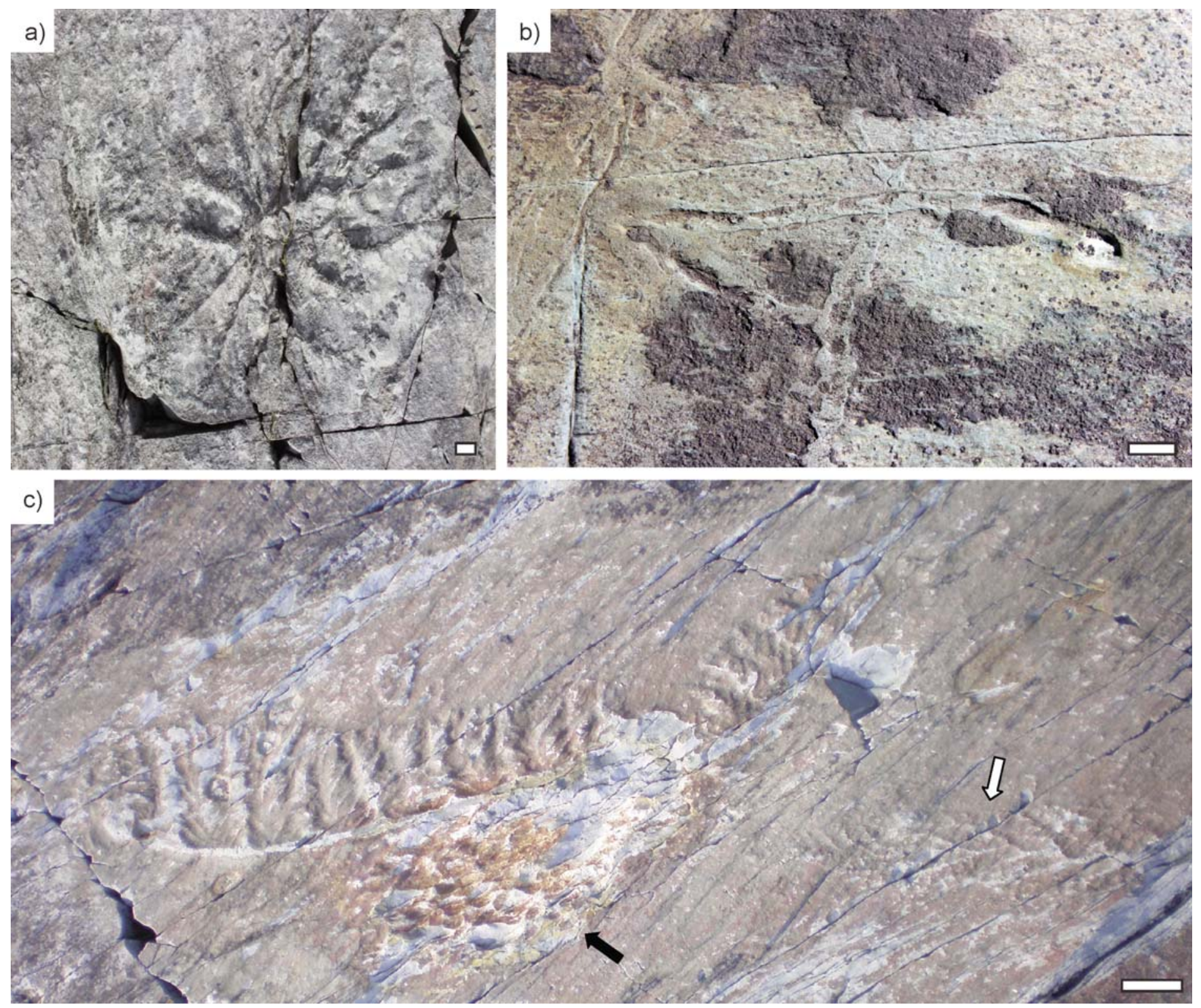

Figure 5. Additional notable fossils from the Mistaken Point Ecological Reserve. a) Hapsidophyllas from the 'B' Surface at Mistaken Point (cf. Landing et al. 1988). b) Horizontal surface trace fossils in the Mistaken Point Formation. c) Pectinifrons abyssalis (centre), Charnia (white arrow), and an Ivesheadiomorph (black arrow), at Mistaken Point North. Scale bars $=10 \mathrm{~mm}$, except $\mathrm{c})=50 \mathrm{~mm}$.

Laflamme 2009; Laflamme et al. 2013; Liu et al. 2015).

Rangeomorphs (Figs. 2, 3, 5; Narbonne 2004) are numerically the most common group of organisms within the Mistaken Point biota, and have received the most attention from researchers. The phylogenetic position of these frondose forms, with their characteristic branching units that repeat at finer scales in a self-similar manner, has proven difficult to constrain, and they have variously been allied to organisms of fungal grade (Peterson et al. 2003), algae (Ford 1958), stem- or crown-group animals (Narbonne 2005), or a 'failed experiment' towards the base of animal evolution (Narbonne 2004; Narbonne et al. 2007). Since morphology alone has so far been unable to confidently place the rangeomorphs within the tree of life, researchers have turned to alternative means in attempting to determine their phylogenetic position. Assuming the organisms are preserved in life position, the extensive MPER fossil assemblages can be interpreted as faithful reflections of census populations of benthic paleocommunities (e.g. Clapham et al. 2003; though see Liu et al. 2015). MPER is therefore an almost unique natural laboratory for paleoecological research, and its fossils have contributed enormously to global understanding of Ediacaran community structure and ecology. Modern ecological techniques have therefore been applied to the assemblages to investigate aspects of paleoecology such as community structure and reproductive strategies (Clapham et al. 2003; Darroch et al. 2013; Mitchell et al. 2015).

Assessment of the population structure of several rangeomorph taxa on individual bedding planes revealed that they

1). http://www.geosciencecanada.ca 
occur as single cohorts with wide variance in the size of individuals, which was interpreted as evidence of a continuous reproductive strategy (Darroch et al. 2013). Meanwhile, the clustered spatial distribution of the rangeomorph Fractofusus (Fig. 2b) may suggest a complex reproductive strategy involving both stolon-like reproduction and the release of waterborne propagules for that taxon (Mitchell et al. 2015). Other paleoecological studies have suggested that rangeomorph ecosystems were structured in a similar way to those of modern benthic animals (Clapham et al. 2003; though see Liu et al. 2015). Efforts to determine the preservational history of specimens, and the impact of microbial activity on the macrobenthos, have also helped to distinguish true biological characters from taphonomic artefacts (Liu et al. 2011, 2015; Laflamme et al. 2012a; Antcliffe et al. 2015; Liu 2016).

Rangeomorph feeding strategies have been investigated from morphological, modelling, and theoretical standpoints, and have led to competing suggestions that rangeomorphs may have been filter feeders (Narbonne 2005) or osmotrophs (Laflamme et al. 2009; Ghisalberti et al. 2014). Another promising avenue of research is into the growth and development of rangeomorphs (and indeed Ediacaran organisms in general). The only previous detailed study of rangeomorph growth suggested that the genus Charnia possesses a growth polarity that is incompatible with that of extant pennatulacean cnidarians (to which frondose taxa had previously been compared, cf. Jenkins and Gehling 1978), thereby refuting a potential relationship to those organisms (Antcliffe and Brasier 2007). Expansion of such developmental reasoning to consider other taxa potentially offers a powerful way to distinguish between competing phylogenetic positions. Discoveries of small specimens in MPER, interpreted as 'juvenile' growth stages (Fig. 3c-e; Liu et al. 2012), ensure that the site will remain integral to research in this area as the surfaces are studied at finer and finer scales.

\section{Stratigraphy and Paleoenvironmental Interpretation}

Ediacaran fossils in Newfoundland occur largely in turbiditic facies of the $\sim 2000 \mathrm{~m}$-thick Conception and St. John's groups. These units are considered to have been deposited in axial basin and slope depositional settings, close to a volcanic island arc complex (Wood et al. 2003). Fossils are found mostly in the Drook, Briscal, Mistaken Point and Trepassey formations, which reflect a broadly shallowing-upwards marine succession (Fig. 1). The organisms are preserved as cast or mould impressions of their exterior surfaces on the tops of hemipelagite beds, and often lie beneath volcanic tuffite layers (Anderson 1978; Narbonne 2005). This sedimentary relationship is responsible for their modern exposure as extensive bedding plane assemblages, since the tuffite layers typically weather preferentially off the surfaces, uncovering the fossils beneath (Narbonne 2005). The tuffite layers were long thought to be the primary agents of fossil preservation (the Conception-type preservation of Narbonne 2005), but recent petrological studies have revealed thin veneers of pyrite on bedding surfaces (Liu 2016), suggesting that the 'death mask' taphonomic mode postulated for other global Ediacaran fossil localities (Gehling
1999; Gehling et al. 2005) may also play a key role in fossil preservation in Newfoundland. This process is considered to involve bacterial sulphate reduction of organic matter in the early stages of burial, producing hydrogen sulphide, which would have reacted with iron in the sediment to create a pyritic 'death mask' over the surface of both the organisms and the surrounding microbial mats (Gehling 1999), permitting replication of their external morphology prior to significant decay.

In the absence of evidence for shallow marine sedimentation throughout hundreds of metres of succession, the MPER depositional environments are considered to have been deep marine (Misra 1969a, 1981; Anderson 1978; Wood et al. 2003). Frondose fossils are commonly found oriented in a similar direction on individual surfaces, suggesting that they were benthic and preserved in a life position on the seafloor. They are often aligned at an angle $90^{\circ}$ to the paleoslope direction indicated by cross-bedding directions in the surrounding turbidites (e.g. Wood et al. 2003; Flude and Narbonne 2008), leading to the suggestion that they have been aligned by contour currents, with hemipelagic siltstone interbedded with the turbidites interpreted as contourites (Wood et al. 2003; Ichaso et al. 2007). A deep marine environment, assumed to be below the photic zone, would have been inhospitable to photosynthetic organisms. Phylogenetic affinities for the Ediacaran organisms that would require photosynthesis (algae and plants) have therefore been largely rejected (e.g. Laflamme and Narbonne 2008).

In recent years, there have been persistent claims in the literature that the Mistaken Point sections include terrestrial deposits, specifically tempestites, tsunamites, and paleosols (Retallack 2010, 2011, 2013, 2016). These suggestions, made on the basis of sedimentological and geochemical investigations, would imply that the Ediacaran biota lived on land, lending support to the suggestion that many Ediacaran macroorganisms could have been lichens (Retallack 1994). This terrestrial assessment of the Conception and St. John's groups at MPER is demonstrably incorrect, due to the convincing evidence for abundant debris flows and turbidites (Fig. 4; Wood et al. 2003; Liu et al. 2014b), and a complete absence of evidence for terrestrial emergence. Prominent surface undulations on several horizons (Fig. 4b), initially discussed as possible wave ripples (Dalrymple et al. 1999), are now accepted by those and other authors to lie within deep marine sediments (cf. Wood et al. 2003), and recognized to be tectonic in origin (e.g. Matthews et al. 2017). Furthermore, several of the taxa found in the MPER succession have also been found in marine sandstone (e.g. Gehling and Droser 2013) and carbonate rocks (e.g. Grazhdankin et al. 2008) elsewhere in the world. It should be noted that demonstrably shallow marine, fluvial and subaerial Ediacaran deposits higher in the section elsewhere in Newfoundland (the St. John's and Signal Hill groups) are not known to contain macrofossils.

\section{Geochronology and Geochemistry}

Radiometric dating of zircon crystals within the volcanic tuffs that overlie many fossil-bearing bedding planes (e.g. Fig. 4c) indicates that the oldest macro-organisms in the MPER 
appeared $\sim 570 \mathrm{Ma}$ (Pu et al. 2016). This puts them just a few million years after the end of the Gaskiers glaciation event (Narbonne and Gehling 2003), a short and possibly regional glaciation that occurred around 581-580 Ma (Pu et al. 2016). The sheer size of some of the earliest Mistaken Point taxa Trepassia specimens can be over a metre in length (Fig. 3a) strongly suggests a greater, as yet undocumented antiquity to some Ediacaran macrofossil lineages. Ediacaran macrofossils persist until $\sim 560 \mathrm{Ma}$ in Newfoundland, giving them an older stratigraphic range than most other global Ediacaran localities (such as the Australian Flinders Ranges, or the White Sea region in Russia, both of which are considered to have been deposited $\sim 560-550 \mathrm{Ma}$; Martin et al. 2000), but one that is broadly equivalent to sites in Charnwood Forest, U.K. (Noble et al. 2015). Zircon grains from directly above the 'E' Surface have been dated by U-Pb TIMS as $565 \mathrm{Ma}$ (Benus 1988; Pu et al. 2016). Additional fossil-bearing surfaces in the MPER are in the process of being dated in order to better constrain rates of sedimentation and evolution.

Only a handful of geochemical studies have been published from the Reserve. Bulk sampling through MPER and nearby sections on the Avalon Peninsula permitted investigation of late Ediacaran redox conditions (via iron speciation techniques), and suggested that the fossil-bearing strata of the Drook to Trepassey formations were deposited in an oxygenated water column, with low total organic carbon (TOC) and sulphide concentrations (Canfield et al. 2007). Elemental data from some of the tuffs within the Reserve confirm a predominantly dacitic composition for the volcaniclastic deposits (Retallack 2014). The siliciclastic sedimentary rocks of the Conception and St. John's groups are not amenable to measuring certain proxies such as stable carbon isotopes, and the application of more recently developed geochemical proxies has largely not yet been attempted.

\section{FUTURE DIRECTIONS AND CONCLUSIONS}

The rocks and fossils of MPER have played a key role in shaping scientific understanding of the early development of Ediacaran macrofossil assemblages, but they continue to offer enormous potential for future research. This is evidenced by newly discovered surfaces such as the 'Brasier Surface' in the Briscal Formation (Fig. 6), which exhibits exceptional fossil abundance and preserved morphological detail. In addition to permitting the identification of new taxa, such preservational quality enables recognition of interactions between individual specimens, and assessment of spatial relationships between taxa. The application of new techniques and approaches to Ediacaran fossils, including spatial statistical analyses (Mitchell et al. 2015), study of growth and development, ancestral state reconstruction (Gold et al. 2015) and fluid modelling (Rahman et al. 2015), will undoubtedly continue to shed light on their original biology and ecology. Microfossil studies have not been systematically undertaken within MPER since the 1970s (and even then most samples from within the Reserve yielded no microfossils; Hofmann et al. 1979), but modern techniques may offer hope of obtaining a more detailed microfossil record. Biomarker studies have never been conducted, although the low organic carbon content of the sections (Canfield et al. 2007) suggests that obtaining biomarkers may not be possible.

Non-paleobiological disciplines also have considerable potential for further research within the Reserve. Although paleomagnetic data were collected as early as the 1970s, MPER-specific readings that could assist in constraining the paleogeographic position of the region have not yet been published (Thomas et al. 2015). Previous bulk geochemical analyses examined iron speciation, sulphur isotopes and carbon content (Canfield et al. 2007), but studies of trace elements or clay mineralogy are yet to be undertaken. The Reserve contains spectacular examples of faulting, folding, and diverse cleavage patterns (e.g. Fig. 4b), and yet the structural geology has only been studied at a coarse regional scale (Williams and King 1979). The volcanic tuffites that commonly cover the fossil surfaces also represent prime targets for future work, not only in terms of their geochemistry (Retallack 2014), but for their potential to yield high-precision radiometric dates for fossil surfaces to further constrain rates of evolution and sedimentation. The wider regional stratigraphic context also requires constraint, for example to investigate the relationship between the Conception Group and the contemporaneously deposited but non-fossil-bearing Musgravetown and Connecting Point groups situated $\sim 100-200 \mathrm{~km}$ to the west (Pu et al. 2016). All of the above suggested studies would enrich our understanding of the MPER biota, and permit tighter integration into global studies of Ediacaran evolution.

In the 50 years since the discovery of Ediacaran macrofossils at Mistaken Point, MPER has revealed many often unexpected facets to Ediacaran paleobiology, and has been integral in shaping our understanding of the Ediacaran macrobiota. A literal reading of the existing data would suggest that the earliest Ediacaran macro-organisms were largely sessile communities of predominantly frondose organisms, and that they were quite different in their composition to the more diverse, motile, shallow-water assemblages of the later Ediacaran. However, rare early motile animals, evidenced by horizontal surface traces found at Mistaken Point (Liu et al. 2010), appear to represent the vanguard of a significant late Ediacaran increase in behavioural and ecological complexity that culminated in the diversification of animal life in the Cambrian. Whether the Ediacaran macrobiota really did first evolve in deep-marine habitats, and whether its component species were animals or entirely unrelated taxa, remain tantalising but currently unanswered questions. As MPER enters a new chapter in its history as a World Heritage Site, with all the challenges and opportunities that status brings, we can be confident that this truly remarkable locality will continue to yield new information, and that it will shape our thinking on Ediacaran paleobiology for many years to come.

\section{ACKNOWLEDGEMENTS}

Thanks are extended to A. Kerr and B. Murphy for inviting this article. Financial support to AGL from a NERC Independent Research Fellowship [grant number NE/ L011409/2], and to JJM from MITACS and the Government of Newfoundland and Labrador, is acknowledged, as is the continued support of the Natural Areas Section. Readers are advised that access to MPER for scientific research is by 

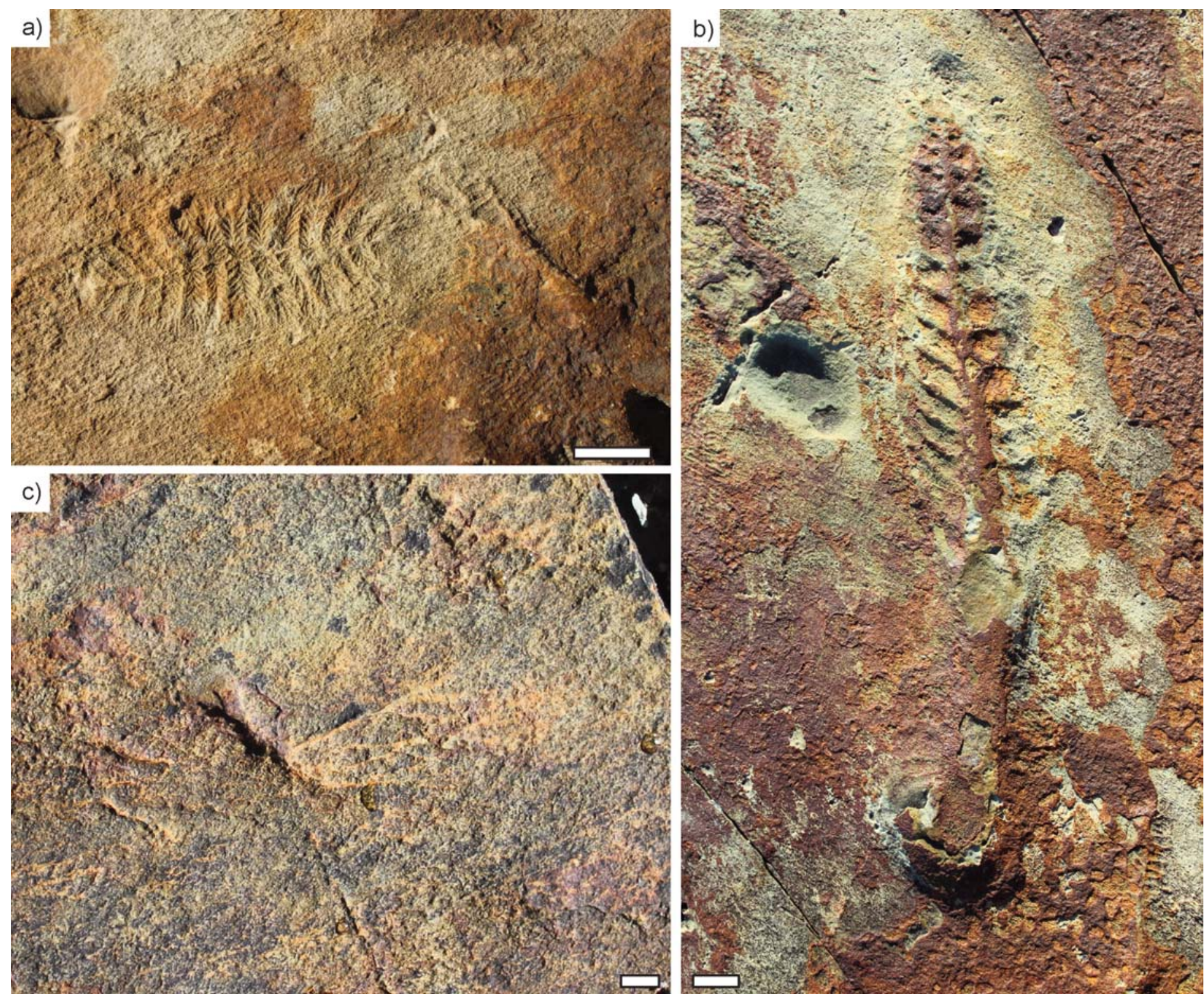

Figure 6. Ediacaran macrofossils on the recently discovered 'Brasier Surface,' Briscal Formation, Mistaken Point Ecological Reserve. This surface is remarkable for its very high fossil densities (>100 individuals $\left./ \mathrm{m}^{2}\right)$, and their particularly fine preservation. a) Fractofusus andersoni (centre left) and Beotbukis plumosa (centre right). b) Charniodiscus sp. surrounded by red and orange iron oxides, which are interpreted as the modern oxidative weathering products of an originally pyritic surface veneer (Liu 2016). c) Primocandelabrum sp. Scale bars $=10 \mathrm{~mm}$.

Newfoundland and Labrador Natural Areas Section, Land Management Division permit only. Permit application information and forms are available here: http://www.flr.gov.nl.ca/natural_areas/wer/r_mpe/permits.html. M. Laflamme, R. Thomas, and one anonymous reviewer are thanked for helpful comments on this manuscript.

\section{REFERENCES}

Anderson, M.M., 1978, Ediacaran fauna, in Lapedes, D.N., ed., Yearbook of Science and Technology: McGraw-Hill, New York, p. 146-149.

Anderson, M.M., and Conway Morris, S., 1982, A review, with descriptions of four unusual forms, of the soft-bodied fauna of the Conception and St. John's groups (Late Precambrian), Avalon Peninsula, Newfoundland: Proceedings of the Third North American Paleontological Convention, v. 1, p. 1-8.

Anderson, M.M., and Misra, S.B., 1968, Fossils found in the Pre-Cambrian Conception Group of South-eastern Newfoundland: Nature, v. 220, p. 680-681, https://doi.org/10.1038/220680a0.

Antcliffe, J.B., and Brasier, M.D., 2007, Charnia and sea pens are poles apart: Journal of the Geological Society, v. 164, p. 49-51, https://doi.org/10.1144/001676492006-080

Antcliffe, J.B., Hancy, A.D., and Brasier, M.D., 2015, A new ecological model for the $\sim 565$ Ma Ediacaran biota of Mistaken Point, Newfoundland: Precambrian Research, v. 268, p. 227-242, https://doi.org/10.1016/i.precamres.2015.06.015.

Attenborough, D., 2010, David Attenborough's First Life: A Journey Back in Time with Matt Kaplan: HarperCollins UK, London, 288 p.

Bamforth, E.L., and Narbonne, G.M., 2009, New ediacaran rangeomorphs from Mistaken Point, Newfoundland, Canada: Journal of Paleontology, v. 83, p. 897 913, https://doi.org/10.1666/09-047.1

Bamforth, E.L., Narbonne, G.M., and Anderson, M.M., 2008, Growth and ecology of a multi-branched Ediacaran Rangeomorph from the Mistaken Point assemblage, Newfoundland: Journal of Paleontology, v. 82, p. 763-777, https://doi.org/10.1666/07-112.1

Benus, A.P., 1988, Sedimentological context of a deep-water Ediacaran fauna (Mistaken Point, Avalon Zone, eastern Newfoundland), in Landing, E., Narbonne, G.M., and Myrow, P.M., eds., Trace Fossils, Small Shelly Fossils and the Precam- 
brian-Cambrian Boundary: New York State Museum and Geological Survey Bulletin, v. 463, p. 8-9.

Billings, E., 1872, On some fossils from the Primordial rocks of Newfoundland: Naturaliste Canadien, v. 6, p. 465-479.

Boag, T.H., Darroch, S.A.F., and Laflamme, M., 2016, Ediacaran distributions in space and time: testing assemblage concepts of earliest macroscopic body fossils: Paleobiology, v. 42, p. 574-594, https://doi.org/10.1017/pab.2016.20.

Bosak, T., Lahr, D.J.G., Pruss, S.B., Macdonald, F.A., Dalton, L., and Matys, E., 2011a, Agglutinated tests in post-Sturtian cap carbonates of Namibia and Mongolia: Earth and Planetary Science Letters, v. 308, p. 29-40, https://doi.org/ 10.1016/j.epsl.2011.05.030.

Bosak, T., Macdonald, F., Lahr, D., and Matys, E., 2011b, Putative Cryogenian ciliates from Mongolia: Geology, v. 39, p. 1123-1126, https://doi.org/10.1130/ G32384.1.

Bosak, T., Lahr, D.J.G., Pruss, S.B., Macdonald, F.A., Gooday, A.J., Dalton, L., and Matys, E.D., 2012, Possible early foraminiferans in post-Sturtian (716-635 Ma) cap carbonates: Geology, v. 40, p. 67-70, https://doi.org/10.1130/G32535.1.

Bottjer, D.J., Hagadorn, J.W., and Dornbos, S.Q., 2000, The Cambrian substrate revolution: GSA Today, v. 10, p. 1-7.

Boyce, W.D., and Reynolds, K., 2008, The Ediacaran fossil Aspidella terranovica Billings, 1872 from St John's Convention Centre test pit CjAe-33: Newfoundland and Labrador Department of Natural Resources Geological Survey, Current Research, v. 08-1, p. 55-61.

Boyle, R.A., Dahl, T.W., Dale, A.W., Shields-Zhou, G.A., Zhu, M., Brasier, M.D. Canfield, D.E., and Lenton, T.M., 2014, Stabilization of the coupled oxygen and phosphorus cycles by the evolution of bioturbation: Nature Geoscience, v. 7, p. 671-676, https://doi.org/10.1038/ngeo2213.

Brasier, M.D., and Antcliffe, J.B., 2009, Evolutionary relationships within the Avalonian Ediacara biota: new insights from laser analysis: Journal of the Geological Society, v. 166, p. 363-384, https://doi.org/10.1144/0016-76492008-011.

Brasier, M.D., Cowie, J., and Taylor, M., 1994, Decision on the Precambrian-Cambrian boundary: Episodes, v. 17, p. 95-100.

Brasier, M.D., Antcliffe, J.B., and Liu, A.G., 2012, The architecture of Ediacaran fronds: Palaeontology, v. 55, p. 1105-1124, https://doi.org/10.1111/j.14754983.2012.01164.x.

Bristow, T.F., and Kennedy, M.J., 2008, Carbon isotope excursions and the oxidant budget of the Ediacaran atmosphere and ocean: Geology, v. 36, p. 863-866, https://doi.org/10.1130/G24968A.1.

Buatois, L.A., and Mángano, M.G., 2011, Ichnology: Organism-substrate interactions in space and time: Cambridge University Press, Cambridge, 358 p., https://doi.org/10.1017/CBO9780511975622.

Budd, G.E., and Jensen, S., 2017, The origin of the animals and a 'Savannah' hypothesis for early bilaterian evolution: Biological Reviews, v. 92, p. 446-473, https://doi.org/10.1111/brv.12239.

Buss, L.W., and Seilacher, A., 1994, The Phylum Vendobionta: a sister group of the Eumetazoa?: Paleobiology, v. 20, p. 1-4, https://doi.org/10.1017/ S0094837300011088.

Butterfield, N.J., 2005, Probable Proterozoic fungi: Paleobiology, v. 31, p. 165-182, https://doi.org/10.1666/0094-8373(2005)031<0165:PPF>2.0.CO;2.

Butterfield, N.J., 2009, Modes of pre-Ediacaran multicellularity: Precambrian Research, v. 173, p. 201-211, https://doi.org/10.1016/i.precamres.2009.01.008.

Callow, R.H.T., and Brasier, M.D., 2009, Remarkable preservation of microbial mats in Neoproterozoic siliciclastic settings: Implications for Ediacaran taphonomic models: Earth-Science Reviews, v. 96, p. 207-219, https://doi.org/10.1016/ j.earscirev.2009.07.002

Canfield, D.E., Poulton, S.W., and Narbonne, G.M., 2007, Late-Neoproterozoic deep-ocean oxygenation and the rise of animal life: Science, v. 315, p. 92-95, https://doi.org/10.1126/science.1135013.

Catling, D.C., Glein, C.R., Zahnle, K.J., and McKay, C.P., 2005, Why $\mathrm{O}_{2}$ is required by complex life on habitable planets and the concept of planetary "oxygenation time": Astrobiology, v. 5, p. 415-438, https://doi.org/10.1089/ast.2005.5.415.

Clapham, M.E., 2011, Ordination methods and the evaluation of Ediacaran communities, in Laflamme, M., Schiffbauer, J.D., and Dornbos, S.Q., eds., Quantifying the Evolution of Early Life: Topics in Geobiology, v. 36, Springer Science+Business Media B.V., p. 3-21, https://doi.org/10.1007/978-94-0070680-4_1.

Clapham, M.E., and Narbonne, G.M., 2002, Ediacaran epifaunal tiering: Geology, v. 30, p. 627-630, https://doi.org/10.1130/0091-7613(2002)030<0627:EET > 2.0.CO;2.

Clapham, M.E., Narbonne, G.M., and Gehling, J.G., 2003, Paleoecology of the oldest known animal communities: Ediacaran assemblages at Mistaken Point, Newfoundland: Paleobiology, v. 29, p. 527-544, https://doi.org/10.1666/00948373(2003)029<0527:POTOKA > 2.0.CO;2.
Clapham, M.E., Narbonne, G.M., Gehling, J.G., Greentree, C., and Anderson, M.M., 2004, Thectardis avalonensis: A new Ediacaran fossil from the Mistaken Point biota, Newfoundland: Journal of Paleontology, v. 78, p. 1031-1036, https://doi.org/10.1017/S0022336000043857.

Cloud Jr., P.E., 1968, Atmospheric and hydrospheric evolution on the primitive Earth: Science, v. 160 , p. 729-736, https://doi.org/10.1126/ science.160.3829.729.

Conway Morris, S., 1985, The Ediacaran biota and early metazoan evolution: Geological Magazine, v. 122, p. 77-81, https://doi.org/10.1017/ S0016756800034129.

Conway Morris, S., 1989, Southeastern Newfoundland and adjacent areas (Avalon Zone), in Cowie, J.W., and Brasier, M.D., eds., The Precambrian-Cambrian boundary: Clarendon Press, Oxford, UK, p. 7-39.

Conway Morris, S., 1993, Ediacaran-like fossils in Cambrian Burgess Shale-type faunas of North America: Palaeontology, v. 36, p. 593-635.

Cunningham, J.A., Liu, A.G., Bengtson, S., and Donoghue, P.C., 2017, The origin of animals: Can molecular clocks and the fossil record be reconciled?: BioEssays, v. 39, p. 1-12, e201600120, https://doi.org/10.1002/bies.201600120.

Dalrymple, R.W., Gehling, J.G., and Narbonne, G., 1999, Storm-dominated sedimentation in a tectonically active basin: Implications for the paleoecology of the Ediacaran (Neoproterozoic) biota at Mistaken Point, Newfoundland (Abstract): Geological Society of America Annual Meeting, Denver, Abstracts with Programs, v. 31, p. 362.

Dalziel, I.W.D., 1997, Overview: Neoproterozoic-Paleozoic geography and tectonics: Review, hypothesis, environmental speculation: Geological Society of America Bulletin, v. 109, p. 16-42, https://doi.org/10.1130/00167606(1997)109<0016:ONPGAT>2.3.CO;2

Damman, A.W., 1983, An ecological subdivision of the Island of Newfoundland: Monographiae Biologicae, v. 48, p. 163-206.

Darroch, S.A.F., Laflamme, M., and Clapham, M.E., 2013, Population structure of the oldest known macroscopic communities from Mistaken Point, Newfoundland: Paleobiology, v. 39, p. 591-608, https://doi.org/10.1666/12051.

Darroch, S.A.F., Sperling, E.A., Boag, T.H., Racicot, R.A., Mason, S.J., Morgan, A.S., Tweedt, S., Myrow, P., Johnston, D.T., Erwin, D.H., and Laflamme, M., 2015, Biotic replacement and mass extinction of the Ediacara biota: Proceedings of the Royal Society B: Biological Sciences, v. 282, 20151003, https://doi.org/10.1098/rspb.2015.1003.

Dececchi, T.A., Narbonne, G.M., Greentree, C., and Laflamme, M., 2017, Relating Ediacaran fronds: Paleobiology, p. 171-180, https://doi.org/10.1017/ pab.2016.54

Droser, M.L., and Gehling, J.G., 2015, The advent of animals: The view from the Ediacaran: Proceedings of the National Academy of Sciences of the USA (PNAS), v. 112, p. 4865-4870, https://doi.org/10.1073/pnas.1403669112.

Droser, M.L., Gehling, J.G., and Jensen, S.R., 2006, Assemblage palaeoecology of the Ediacara biota: The unabridged edition?: Palaeogeography, Palaeoclimatology, Palaeoecology, v. 232, p. 131-147, https://doi.org/10.1016/ j.palaeo.2005.12.015.

Dunn, F.S., and Liu, A.G., 2017, Fossil Focus: The Ediacaran biota: Palaeontology Online, v. 7, Article 1, p. 1-15.

Fedonkin, M.A., Gehling, J.G., Grey, K., Narbonne, G.M., and Vickers-Rich, P., 2007, The Rise of Animals: Evolution and Diversification of the Kingdom Animalia: John Hopkins University Press, Baltimore, 326 p.

Fike, D.A., Grotzinger, J.P., Pratt, L.M., and Summons, R.E., 2006, Oxidation of the Ediacaran Ocean: Nature, v. 444, p. 744-747, https://doi.org/10.1038/ nature 05345.

Flude, L.I., and Narbonne, G.M., 2008, Taphonomy and ontogeny of a multibranched Ediacaran fossil: Bradgatia from the Avalon Peninsula of Newfoundland: Canadian Journal of Earth Sciences, v. 45, p. 1095-1109, https://doi.org/ 10.1139/E08-057.

Ford, T.D., 1958, Pre-Cambrian fossils from Charnwood Forest: Proceedings of the Yorkshire Geological Society, v. 31, p. 211-217, https://doi.org/10.1144/ pygs.31.3.211

Gardiner, S., and Hiscott, R.N., 1988, Deep-water facies and depositional setting of the lower Conception Group (Hadrynian), southern Avalon Peninsula, Newfoundland: Canadian Journal of Earth Sciences, v. 25, p. 1579-1594, https://doi.org/10.1139/e88-151.

Gehling, J.G., 1999, Microbial mats in terminal Proterozoic siliciclastics; Ediacaran death masks: PALAIOS, v. 14, p. 40-57, https://doi.org/10.2307/3515360.

Gehling, J.G., and Droser, M.L., 2013, How well do fossil assemblages of the Ediacara Biota tell time?: Geology, v. 41, p. 447-450, https://doi.org/10.1130/ G33881.1.

Gehling, J.G., and Narbonne, G.M., 2007, Spindle-shaped Ediacara fossils from the Mistaken Point assemblage, Avalon Zone, Newfoundland: Canadian Journal of 
Earth Sciences, v. 44, p. 367-387, https://doi.org/10.1139/e07-003.

Gehling, J.G., Narbonne, G.M., and Anderson, M.M., 2000, The first named Ediacaran body fossil, Aspidella terranovica: Palaeontology, v. 43, p. 427-456, https://doi.org/10.1111/j.0031-0239.2000.00134.x.

Gehling, J.G., Droser, M.L., Jensen, S.R., and Runnegar, B.N., 2005, Ediacaran organisms: relating form and function, in Briggs, D.E.G., ed., Evolving form and function: Fossils and development: Proceedings of a symposium honoring Adolf Seilacher for his contributions to paleontology, in celebration of his $80^{\mathrm{t}}$ birthday, Peabody Museum of Natural History, Yale University, New Haven, CT, p. 43-67.

Ghisalberti, M., Gold, D.A., Laflamme, M., Clapham, M.E., Narbonne, G.M., Summons, R.E., Johnston, D.T., and Jacobs, D.K., 2014, Canopy flow analysis reveals the advantage of size in the oldest communities of multicellular eukaryotes: Current Biology, v. 24, p. 305-309, https://doi.org/10.1016/ j.cub.2013.12.017.

Glaessner, M.F., and Wade, M., 1966, The Late Precambrian fossils from Ediacara, South Australia: Palaeontology, v. 9, p. 599-628

Gold, D.A., Runnegar, B., Gehling, J.G., and Jacobs, D.K., 2015, Ancestral state reconstruction of ontogeny supports a bilaterian affinity for Dickinsonia: Evolution and Development, v. 17, p. 315-324, https://doi.org/10.1111/ede.12168.

Grazhdankin, D., 2004, Patterns of distribution in the Ediacaran biotas: facies versus biogeography and evolution: Paleobiology, v. 30, p. 203-221, https://doi.org/ 10.1666/0094-8373(2004)030<0203:PODITE>2.0.CO;2.

Grazhdankin, D., 2014, Patterns of evolution of the Ediacaran soft-bodied biota: Journal of Paleontology, v. 88, p. 269-283, https://doi.org/10.1666/13-072.

Grazhdankin, D.V., Balthasar, U., Nagovitsin, K.E., and Kochnev, B.B., 2008, Carbonate-hosted Avalon-type fossils in arctic Siberia: Geology, v. 36, p. 803-806, https://doi.org/10.1130/G24946A.1.

Halverson, G.P., Hoffman, P.F., Schrag, D.P., Maloof, A.C., and Rice, A.H.N., 2005, Toward a Neoproterozoic composite carbon-isotope record: Geological Society of America Bulletin, v. 117, p. 1181-1207, https://doi.org/10.1130/B25630.1.

Hofmann, H.J., Hill, J., and King, A.F., 1979, Late Precambrian microfossils, southeastern Newfoundland: Geological Survey of Canada, Current Research, Part B, v. 79-1B, p. 83-98.

Hofmann, H.J., O’Brien, S.J., and King, A.F., 2008, Ediacaran biota on Bonavista Peninsula, Newfoundland, Canada: Journal of Paleontology, v. 82, p. 1-36, https://doi.org/10.1666/06-087.1.

Hoyal Cuthill, J.F., and Conway Morris, S., 2014, Fractal branching organizations of Ediacaran rangeomorph fronds reveal a lost Proterozoic body plan: Proceedings of the National Academy of Sciences of the USA (PNAS), v. 111, p. 13122-13126, https://doi.org/10.1073/pnas.1408542111.

Ichaso, A.A., Dalrymple, R.W., and Narbonne, G.M., 2007, Paleoenvironmental and basin analysis of the late Neoproterozoic (Ediacaran) upper Conception and St. John's groups, west Conception Bay, Newfoundland: Canadian Journal of Earth Sciences, v. 44, p. 25-41, https://doi.org/10.1139/e06-098.

Jenkins, R.J.F., and Gehling, J.G., 1978, A review of frond-like fossils of the Ediacara assemblage: Records of the South Australian Museum, v. 17, p. 347-359.

Jensen, S., Gehling, J.G., and Droser, M.L., 1998, Ediacara-type fossils in Cambrian sediments: Nature, v. 393, p. 567-569, https://doi.org/10.1038/31215.

Johnston, D.T., Poulton, S.W., Goldberg, T., Sergeev, V.N., Podkovyrov, V., Vorob’eva, N.G., Bekker, A., and Knoll, A.H., 2012, Late Ediacaran redox stability and metazoan evolution: Earth and Planetary Science Letters, v. 335-336, p. 25-35, https://doi.org/10.1016/j.epsl.2012.05.010.

Laflamme, M., and Narbonne, G.M., 2008, Ediacaran fronds: Palaeogeography, Palaeoclimatology, Palaeoecology, v. 258, p. 162-179, https://doi.org/10.1016/ j.palaeo.2007.05.020

Laflamme, M., Narbonne, G.M., and Anderson, M.M., 2004, Morphometric analysis of the Ediacaran frond Charniodiscus from the Mistaken Point Formation, Newfoundland: Journal of Paleontology, v. 78, p. 827-837, https://doi.org/ 10.1666/0022-3360(2004)078<0827:MAOTEF>2.0.CO;2.

Laflamme, M., Narbonne, G.M., Greentree, C., and Anderson, M.M., 2007, Morphology and taphonomy of an Ediacaran frond: Charnia from the Avalon Peninsula of Newfoundland, in Vickers-Rich, P., and Komarower, P., eds., The Rise and Fall of the Ediacaran Biota: Geological Society, London, Special Publications, v. 286, p. 237-257, https://doi.org/10.1144/sp286.17.

Laflamme, M., Xiao, S., and Kowalewski, M., 2009, Osmotrophy in modular Ediacara organisms: Proceedings of the National Academy of Sciences of the USA (PNAS), v. 106, p. 14438-14443, https://doi.org/10.1073/pnas.0904836106.

Laflamme, M., Schiffbauer, J.D., and Narbonne, G.M., 2012a, Deep-water microbially induced sedimentary structures (MISS) in deep time: The Ediacaran fossil Ivesheadia, in Noffke, N., and Chafetz, H., eds., Microbial Mats in Siliciclastic Depositional Systems Through Time: Society of Sedimentary Geology, Special Publications, v. 101, p. 111-123, https://doi.org/10.2110/sepmsp.101.111.
Laflamme, M., Flude, L.I., and Narbonne, G.M., 2012b, Ecological tiering and the evolution of a stem: the oldest stemmed frond from the Ediacaran of Newfoundland, Canada: Journal of Paleontology, v. 86, p. 193-200, https://doi.org/10.1666/11-044.1

Laflamme, M., Darroch, S.A.F., Tweedt, S.M., Peterson, K.J., and Erwin, D.H., 2013 The end of the Ediacara biota: Extinction, biotic replacement, or Cheshire Cat?: Gondwana Research, v. 23, p. 558-573, https://doi.org/10.1016/ j.gr.2012.11.004.

Landing, E., Narbonne, G.M., Myrow, P.M., Benus, A.P., and Anderson, M.M., 1988 Faunas and depositional environments of the upper Precambrian through lower Cambrian, southeastern Newfoundland (field trip road log), in Landing, E., Narbonne, G.M., and Myrow, P.M., eds., Trace Fossils, Small Shelly Fossils and the Precambrian-Cambrian Boundary: New York State Museum and Geological Survey Bulletin, v. 463, p. 27-32.

Le Guerroué, E., 2010, Duration and synchroneity of the largest negative carbon isotope excursion on Earth: The Shuram/Wonoka anomaly: Comptes Rendus Geoscience, v. 342, p. 204-214, https://doi.org/10.1016/j.crte.2009.12.008.

Li, Z.X., Bogdanova, S.V., Collins, A.S., Davidson, A., De Waele, B., Ernst, R.E., Fitzsimons, I.C.W., Fuck, R.A., Gladkochub, D.P., Jacobs, J., Karlstrom, K.E., Lu, S., Natapov, L.M., Pease, V., Pisarevsky, S.A., Thrane, K., and Vernikovsky, V., 2008, Assembly, configuration, and break-up history of Rodinia: A synthesis: Precambrian Research, v. 160, p. 179-210, https://doi.org/10.1016/j.precamres.2007.04.021

Liu, A.G., 2016, Framboidal pyrite shroud confirms the 'death mask' model for moldic preservation of Ediacaran soft-bodied organisms: PALAIOS, v. 31, p. 259-274, https://doi.org/10.2110/palo.2015.095.

Liu, A.G., and Brasier, M.D., 2012, A global comparative analysis of Ediacaran fossil localities: Unpublished report submitted to the IUCN/UNESCO, Oxford, UK, $132 \mathrm{p}$.

Liu, A.G., Mcllroy, D., and Brasier, M.D., 2010, First evidence for locomotion in the Ediacara biota from the 565 Ma Mistaken Point Formation, Newfoundland: Geology, v. 38, p. 123-126, https://doi.org/10.1130/G30368.1.

Liu, A.G., McIlroy, D., Antcliffe, J.B., and Brasier, M.D., 2011, Effaced preservation in the Ediacaran biota and its implications for the early macrofossil record: Palaeontology, v. 54, p. 607-630, https://doi.org/10.1111/j.14754983.2010.01024.x.

Liu, A.G., McIlroy, D., Matthews, J.J., and Brasier, M.D., 2012, A new assemblage of juvenile Ediacaran fronds from the Drook Formation, Newfoundland: Journal of the Geological Society, v. 169, p. 395-403, https://doi.org/10.1144/001676492011-094

Liu, A.G., Matthews, J.J., Menon, L.R., McIlroy, D., and Brasier, M.D., 2014a, Haootia quadriformis n. gen., n. sp., interpreted as a muscular cnidarian impression from the Late Ediacaran period ( $560 \mathrm{Ma})$ : Proceedings of the Royal Society B: Biological Sciences, v. 281, 20141202, https://doi.org/10.1098/rspb.2014.1202.

Liu, A.G., McIlroy, D., Matthews, J.J., and Brasier, M.D., 2014b, Confirming the metazoan character of a 565 Ma trace-fossil assemblage from Mistaken Point, Newfoundland: PALAIOS, v. 29, p. 420-430, https://doi.org/10.2110/ palo.2014.011.

Liu, A.G., Kenchington, C.G., and Mitchell, E.G., 2015, Remarkable insights into the paleoecology of the Avalonian Ediacaran macrobiota: Gondwana Research, v. 27, p. 1355-1380, https://doi.org/10.1016/j.gr.2014.11.002.

Lyons, T.W., Reinhard, C.T., and Planavsky, N.J., 2014, The rise of oxygen in Earth's early ocean and atmosphere: Nature, v. 506, p. 307-315, https://doi.org/ 10.1038 /nature13068.

Martin, M.W., Grazhdankin, D.V., Bowring, S.A., Evans, D.A.D., Fedonkin, M.A., and Kirschvink, J.L., 2000, Age of Neoproterozoic bilaterian body and trace fossils, White Sea, Russia: Implications for metazoan evolution: Science, v. 288, p. 841-845, https://doi.org/10.1126/science.288.5467.841.

Mason, S.J., and Narbonne, G.M., 2016, Two new Ediacaran small fronds from Mistaken Point, Newfoundland: Journal of Paleontology, v. 90, p. 183-194, https://doi.org/10.1017/jpa.2016.14.

Matthews, J.J., Liu, A.G., and McIlroy, D., 2017, Post-fossilization processes and their implications for understanding Ediacaran macrofossil assemblages: Geological Society of London, Special Publications, v. 448, SP448-20, https://doi.org/ $10.1144 / \mathrm{sp} 448.20$.

Meades, S.J., 1990, Ecoregions of Newfoundland and Labrador. St. John's, Newfoundland and Labrador: Government of Newfoundland and Labrador, Department of Environment and Conservation, Parks and Natural Areas Division.

Misra, S.B., 1969a, Geology of the Biscay Bay - Cape Race area, Avalon Peninsula, Newfoundland: Unpublished MSc thesis, Memorial University, St. John's, NL, $139 \mathrm{p}$.

Misra, S.B., 1969b, Late Precambrian(?) fossils from southeastern Newfoundland: 
Geological Society of America Bulletin, v. 80, p. 2133-2140, https://dx.doi/ 10.1130/0016-7606(1969)80[2133:LPFFSN]2.0.CO;2.

Misra, S.B., 1981, Depositional environment of the late Precambrian fossil-bearing rocks of southeastern Newfoundland, Canada: Journal of the Geological Society of India, v. 22, p. 375-382.

Mitchell, E.G., Kenchington, C.G., Liu, A.G., Matthews, J.J., and Butterfield, N.J., 2015, Reconstructing the reproductive mode of an Ediacaran macro-organism: Nature, v. 524, p. 343-346, https://doi.org/10.1038/nature14646.

Narbonne, G.M., 2004, Modular construction of early Ediacaran complex life: Science, v. 305, p. 1141-1144, https://doi.org/10.1126/science.1099727.

Narbonne, G.M., 2005, The Ediacara biota: Neoproterozoic origin of animals and their ecosystems: Annual Review of Earth and Planetary Sciences, v. 33, p. 421 442, https://doi.org/10.1146/annurev.earth.33.092203.122519.

Narbonne, G.M., and Gehling, J.G., 2003, Life after snowball: The oldest complex Ediacaran fossils: Geology, v. 31, p. 27-30, https://doi.org/10.1130/00917613(2003)031<0027:LASTOC>2.0.CO;2

Narbonne, G.M., Gehling, J.G., and Vickers-Rich, P., 2007, The Misty Coasts of Newfoundland, in Fedonkin, M.A., Gehling, J.G., Grey, K., Narbonne, G.M., and Vickers-Rich, P., eds., The Rise of Animals: Evolution and Diversification of the Kingdom Animalia: John Hopkins University Press, v. 1, p. 53-68.

Narbonne, G.M., Laflamme, M., Greentree, C., and Trusler, P., 2009, Reconstructing a lost world: Ediacaran rangeomorphs from Spaniard's Bay, Newfoundland: Journal of Paleontology, v. 83, p. 503-523, https://doi.org/10.1666/08072R1.1.

Noble, S.R., Condon, D.J., Carney, J.N., Wilby, P.R., Pharaoh, T.C., and Ford, T.D., 2015, U-Pb geochronology and global context of the Charnian Supergroup, UK: Constraints on the age of key Ediacaran fossil assemblages: Geological Society of America Bulletin, v. 127, p. 250-265, https://doi.org/10.1130/ B31013.1.

O’Brien, S.J., and King, A.F., 2004, Ediacaran fossils from the Bonavista Peninsula (Avalon zone), Newfoundland: Preliminary descriptions and implications for regional correlation: Newfoundland Department of Mines and Energy Geological Survey, Current Research, v. 04-1, p. 203-212.

Peterson, K.J., Waggoner, B., and Hagadorn, J.W., 2003, A fungal analog for Newfoundland Ediacaran fossils?: Integrative and Comparative Biology, v. 43, p. 127-136, https://doi.org/10.1093/icb/43.1.127.

Pu, J.P., Bowring, S.A., Ramezani, J., Myrow, P., Raub, T.D., Landing, E., Mills, A., Hodgin, E., and Macdonald, F.A., 2016, Dodging snowballs: Geochronology of the Gaskiers glaciation and the first appearance of the Ediacaran biota: Geology, v. 44, p. 955-958, https://doi.org/10.1130/G38284.1.

Rahman, I.A., Darroch, S.A.F., Racicot, R.A., and Laflamme, M., 2015, Suspension feeding in the enigmatic Ediacaran organism Tribrachidium demonstrates complexity of Neoproterozoic ecosystems: Science Advances, v. 1, e1500800, https://doi.org/10.1126/sciadv.1500800.

Retallack, G.J., 1994, Were the Ediacaran fossils lichens?: Paleobiology, v. 20, p. 523 544, https://doi.org/10.1017/S0094837300012975.

Retallack, G.J., 2010, First evidence for locomotion in the Ediacara biota from the 565 Ma Mistaken Point Formation, Newfoundland: Comment: Geology, v. 38 p. e223, https://doi.org/10.1130/G31137C.1.

Retallack, G.J., 2011, Neoproterozoic loess and limits to snowball Earth: Journal of the Geological Society, v. 168, p. 289-308, https://doi.org/10.1144/001676492010-051.

Retallack, G.J., 2013, Ediacaran Gaskiers Glaciation of Newfoundland reconsidered: Journal of the Geological Society, v. 170, p. 19-36, https://doi.org/10.1144/ jgs2012-060.

Retallack, G.J., 2014, Volcanosedimentary paleoenvironments of Ediacaran fossils in Newfoundland: Geological Society of America Bulletin, v. 126, p. 619-638, https://doi.org/10.1130/B30892.1.

Retallack, G.J., 2016, Ediacaran sedimentology and paleoecology of Newfoundland reconsidered: Sedimentary Geology, v. 333, p. 15-31, https://doi.org/10.1016/ j.sedgeo.2015.12.001.

Rooney, A.D., Strauss, J.V., Brandon, A.D., and Macdonald, F.A., 2015, A Cryogenian chronology: Two long-lasting synchronous Neoproterozoic glaciations: Geology, v. 43, p. 459-462, https://doi.org/10.1130/G36511.1.

Scotese, C.R., 2009, Late Proterozoic plate tectonics and palaeogeography: a tale of two supercontinents, Rodinia and Pannotia, in Craig, J., Thurow, J., Thusu, B., Whitham, A., and Abutarruma, Y., eds., Global Neoproterozoic Petroleum Systems: The Emerging Potential in North Africa: Geological Society, London, Special Publications, v. 326, p. 67-83, https://doi.org/10.1144/sp326.4.

Seilacher, A., 1989, Vendozoa: Organismic construction in the Proterozoic biosphere: Lethaia, v. 22, p. 229-239, https://doi.org/10.1111/j.1502 3931.1989.tb01332.x.

Seilacher, A., 1992, Vendobionta and Psammocorallia: lost constructions of Precam- brian evolution: Journal of the Geological Society, v. 149, p. 607-613, https://doi.org/10.1144/gsigs.149.4.0607.

Seilacher, A., 1999, Biomat-related lifestyles in the Precambrian: PALAIOS, v. 14, p. 86-93, https://doi.org/10.2307/3515363.

Seilacher, A., 2007, The nature of vendobionts, in Vickers-Rich, P., and Komarower, P., eds., The Rise and Fall of the Ediacaran Biota: Geological Society, London, Special Publications, v. 286, p. 387-397, https://doi.org/10.1144/sp286.28.

Seilacher, A., and Pfluger, F., 1994, From biomats to benthic agriculture: A biohistoric revolution, in Krumbein, W.E., Peterson, D.M., and Stal, L.J., eds., Biostabilization of Sediments: Bibliotheks-und Informationssystem der Carl von Ossietzky Universitat Odenburg, p. 97-105.

Shields-Zhou, G., and Och, L., 2011, The case for a Neoproterozoic oxygenation event: Geochemical evidence and biological consequences: GSA Today, v. 21, p. 4-11, https://doi.org/10.1130/GSATG102A.1.

Smith, E.F., Nelson, L.L., Strange, M.A., Eyster, A.E., Rowland, S.M., Schrag, D.P., and Macdonald, F.A., 2016, The end of the Ediacaran: Two new exceptionally preserved body fossil assemblages from Mount Dunfee, Nevada, USA: Geology, v. 44, p. 911-914, https://doi.org/10.1130/G38157.1.

Thomas, R.G., Narbonne, G.M., Graham, J., Pittman, E., and Breon, C., 2015, Mistaken Point. Nomination for Inscription, UNESCO World Heritage List: Newfoundland and Labrador Department of Environment and Conservation, Parks and Natural Areas Division, Corner Brook, NL, 138 p. Available online at: http://whc.unesco.org/uploads/nominations/1497.pdf.

Vidal, G., and Moczydlowska-Vidal, M., 1997, Biodiversity, speciation, and extinction trends of Proterozoic and Cambrian phytoplankton: Paleobiology, v. 23, p. 230-246, https://doi.org/10.1017/S0094837300016808.

Waggoner, B., 2003, The Ediacaran biotas in space and time: Integrative and Comparative Biology, v. 43, p. 104-113, https://doi.org/10.1093/icb/43.1.104.

Wan B., Yuan X., Chen Z., Guan C., Pang K., Tang Q., and Xiao S., 2016, Systematic description of putative animal fossils from the early Ediacaran Lantian Formation of South China: Palaeontology, v. 59, p. 515-532, https://doi.org/ $10.1111 /$ pala.12242.

Warren, L.V., Pacheco, M.L.A.F., Fairchild, T.R., Simões, M.G., Riccomini, C., Boggiani, P.C., and Cáceres, A.A., 2012, The dawn of animal skeletogenesis: Ultrastructural analysis of the Ediacaran metazoan Corumbella werneri: Geology, v. 40, p. 691-694, https://doi.org/10.1130/G33005.1.

Williams, H., and King, A.F., 1979, Trepassey Map Area, Newfoundland: Geological Survey of Canada, Memoir 389, 24 p., https://doi.org/10.4095/124055.

Wood, D.A., Dalrymple, R.W., Narbonne, G.M., Gehling, J.G., and Clapham, M.E., 2003, Paleoenvironmental analysis of the late Neoproterozoic Mistaken Point and Trepassey formations, southeastern Newfoundland: Canadian Journal of Earth Sciences, v. 40, p. 1375-1391, https://doi.org/10.1139/e03-048.

Wood, R.A., 2011, Paleoecology of the earliest skeletal metazoan communities: Implications for early biomineralization: Earth-Science Reviews, v. 106, p. 184 190, https://doi.org/10.1016/j.earscirev.2011.01.011.

Xiao S., and Laflamme, M., 2009, On the eve of animal radiation: phylogeny, ecology and evolution of the Ediacara biota: Trends in Ecology and Evolution, v. 24, p. 31-40, https://doi.org/10.1016/j.tree.2008.07.015.

Yin Z., Zhu M., Davidson, E.H., Bottjer, D.J., Zhao F., and Tafforeau, P., 2015, Sponge grade body fossil with cellular resolution dating $60 \mathrm{Myr}$ before the Cambrian: Proceedings of the National Academy of Sciences of the USA (PNAS), v. 112, p. E1453-E1460, https://doi.org/10.1073/pnas.1414577112.

Yuan X., Chen Z., Xiao S., Zhou C., and Hua H., 2011, An early Ediacaran assemblage of macroscopic and morphologically differentiated eukaryotes: Nature, v. 470, p. 390-393, https://doi.org/10.1038/nature09810.

Zakrevskaya, M., 2014, Paleoecological reconstruction of the Ediacaran benthic macroscopic communities of the White Sea (Russia): Palaeogeography, Palaeoclimatology, Palaeoecology, v. 410, p. 27-38, https://doi.org/10.1016/ j.palaeo.2014.05.021.

Zhu S., Zhu M., Knoll, A.H., Yin Z., Zhao F., Sun S., Qu Y., Shi M., and Liu H., 2016, Decimetre-scale multicellular eukaryotes from the 1.56-billion-year-old Gaoyuzhuang Formation in North China: Nature Communications, v. 7, 11500, https://doi.org/10.1038/ncomms11500.

\section{Received November 2016}

Accepted as revised March 2017

First published on the web June 2017 